Bilecik Şeyh Edebali Üniversitesi Sosyal Bilimler Dergisi - Bilecik Şeyh Edebali University Journal of Social Sciences

ISSN/E-ISSN: $2548-088 X$

DOI: $10.33905 /$ bseusbed.688144

Corresponding Author/Sorumlu Yazar:

Selma GÖKTÜRK ÇETINKAYA, Bilecik Seyh Edebali Üniversitesi, Fen-Edebiyat Fakültesi, Tarih Bölümü, selma.cetinkaya@bilecik.edu.tr
Submitted/Başvuru: 11.02 .2020

Accepted/Kabul: 04.03.2020

Citation/Atıf: GÖKTÜRK CETINKKAYA， S. (2020). TürkiyeAzerbaycan İlişkilerinin Askeri Boyutu ve Jandarma Merkezli Yardımlar (1992-2014). Bilecik Şeyh Edebali Üniversitesi Sosyal Bilimler Dergisi, 5/1, 15-40. DOI: 10.33905/bseusbed.688144

Orcid: 0000-0001-6828-1679

RESEARCH ARTICLE / ARAŞTIRMA MAKALESİ

\title{
Türkiye-Azerbaycan İlişkilerinin Askeri Boyutu ve Jandarma Merkezli Yardımlar (1992-2014)
}

\section{Military Dimension of Turkey-Azerbaijan Relations and Gendarmerie-Centered Aids} (1992-2014)

\author{
Selma GÖKTÜRK ÇETINKAYA ${ }^{1}$
}

\section{$\ddot{O} z$}

1991'de Azerbaycan'ın bağımsızlığına kavuşması sonrası kendisini ilk tanıyan ülke Türkiye Cumhuriyeti olmuştur. İki kardeş ülkenin bu tarihte başlayan iyi ilişkileri siyaset, ekonomi, enerji, eğitim, sağlık ve turizm gibi pek çok farklı alanda kendini göstermiştir. Ayrıca ülkenin tehditlere açık bir coğrafyada yer alması, güvenlik noktasında da birlikte hareket etmeleri gerekliliğini doğurmuştur. Bu minval üzere yeni yapılanan Azerbaycan'ı askeri açıdan destekleyen Türkiye, iç güvenlikle ilgili olarak da eğitim ve ekonomi temelli yardımlarını esirgememiştir. Askeri eğitim noktasında Türkiye ile Azerbaycan arasında 1992'de imzalanan Askeri Eğitim İş̧birliği Anlaşması, bu alandaki desteğin başlangıcıdır. Ayrıca dönemin cumhurbaşkanı Turgut Özal'ın 1993'te Azerbaycan ziyareti esnasında Dağlık Karabağ sorununda Ermeniler savaşı durdurmadığı takdirde Türkiye ile Azerbaycan arasında askeri ittifakın oluşturulmasının gerekliliğine vurgu yapması bu bağlamda okunmalıdır. Nitekim Özal'ın açıklamasıyla eş zamanlı TBMM'de onaylanmış olan Askeri Eğitim İşbirliği Anlaşması'nın gereğince 1994 itibariyle Azerbaycan iç güvenliğini sağlayacak askeri statüdeki kolluk kuvvetlerinin eğitimine başlanmıştır.

İki ülke arasındaki işbirliği, 2013’te Kırgızistan'ın da katılımıyla Avrasya Askeri Statülü Kolluk Kuvvetleri Teşkilatı'nın kurulmasını beraberinde getirmiştir. Jandarma Genel Komutanlığı ile Dahili Koşunlar Komutanlığı'nın münasebetlerini on iki yıllık zaman dilimi içerisinde değerlendiren makale, Türkiye-Azerbaycan askeri yönlü ilişkilerinin jandarma eksenli çalışmada yeterince ele alınmamış olması nedeniyle hazırlanmıştır. Makale, var olan eksikliği doldurmak ve yapılacak çalışmalara rehberlik etmek gayesiyle hazırlanmıştır.

Anahtar Kelimeler: Kafkas Türkiye, Azerbaycan, Jandarma Genel Komutanlığı, Azerbaycan Dâhili Koşunlar Komutanlığı, Avrasya Askeri Statülü Kolluk Kuvvetleri Teşkilatı.

\begin{abstract}
In 1991, Azerbaijan gained its independence. It was the first country to recognize the Republic of Turkey. The good relations of the two frendly countries starting from this date have been seen in many different fields such as politics, economy, education, health and tourism. In addition, the fact that both countries are located in a geography open to threats has led to the necessity of acting together at the security point. Therefore, Turkey has supported Azerbaijan in military terms the new structure. Turkey, as the internal security related training requirements, as well as help the way the economy has been spared. Military Training Cooperation Agreement signed by the middle of 1992, the beginning of military training cooperation of Azerbaijan with Turkey. Turkey's support for Azerbaijan began with this deal. In addition, Turgut Özal, the president of the period, went to Azerbaijan in April 1993. Özal, Armenians in NagornoKarabakh said it was necessary to establish a military alliance between Azerbaijan and Turkey does not
\end{abstract}

\footnotetext{
${ }^{1}$ Dr. Öğr. Üyesi, Bilecik Şeyh Edebali Üniversitesi, selma.gokturk@bilecik.edu.tr
} 
stop the war. As a matter of fact, the Military Education Cooperation Agreement approved in the Turkish Grand National Assembly was approved simultaneously with the statement of Özal. Within the scope of this agreement, as of 1994, training of law enforcement officers with military status that will ensure the internal security of Azerbaijan started. In 1994, the Security Cooperation Agreement was also signed by the Interior Ministers of the two countries.

Cooperation between the two countries was transformed into a restructuring in 2013, and with the participation of Kyrgyzstan, the Eurasia Military Status Law Enforcement Agency (TAKM) was established. This article evaluates the mutual relations of the Gendarmerie General Command and Internal Combinations Command within a period of twelve years. Military relations between Turkey and Azerbaijan, the gendarmerie axis has been adequately dealt with in a study. For this reason, this article has been prepared. The article has been prepared with the aim of filling the existing deficiency and guiding the future studies.

Key Words: Turkey, Azerbaijan, Gendarmerie General Command, the Command of Internal Affairs of the Republic of Azerbaijan, the Association of the Eurasian Law Enforcement Military Status Law Enforcement Forces with Military Status.

\section{Giriş}

Soğuk Savaş Döneminin SSCB'nin yıkılışıyla daha doğru ifadeyle Sovyet Bloğunun dağılmasıyla sona ermesi, kuruluşunu yeni sağlamış ülkelerin nasıl bir politika izleyecekleri sorusunu da beraberinde getirmiştir. Doksanlı yıllarda, bir yandan dünya siyaseti küreselleşmeye doğru gidişi desteklerken bir yandan da henüz kurulmuş olan devletler güçlenmeye çalışmaktaydılar. SSCB'nin yıkılışıyla eş zamanlı kurulan devletlerden olan Azerbaycan da aynı süreçte gücünü artırmak için çaba sarf etmesi gerekirken Ermenistan'ın Rusya destekli saldırılarıyla karşı karşıya kalmıştır. Özellikle askeri yönden yetersiz durumda olan Azerbaycan'ın bağımsızlığı itibariyle bu sorunlarla uğraşmak zorunda kalması oldukça zorlanmasına neden olmuştur. Türkiye'nin askeri boyutlu yardımlara mesafeli durması, yaşananları iç mesele olarak görmesi muhalefetin ve Azerbaycan'ın eleştirilerini beraberinde getirmiştir. $\mathrm{Bu}$ süreçte kendi sınırları dahilindeki terör hareketliliğinin göz önünde bulundurulması gerekliliğini de belirterek Türkiye'nin üye olduğu devletlerarası teşkilatlar ve anlaşmalara bağlılığını gerekçe olarak sunduğu durumları da görmek mümkün. Bu durumların zamanla azaldığını ve Azerbaycan'a yönelik desteğin askeri boyutta da verilmeye başlandığını söyleyebiliriz. Nitekim Azerbaycan'1 kardeş ülke söylemiyle destekleyen Türkiye'nin bölgesel ve küresel kapsamlı münasebetlerindeki rolü oldukça fazladır. Millet mefhumunun öne çıkarılmasıyla bölgesel birlikteliğe giden Türkiye ve Azerbaycan, otuz yıla yaklaşan süre zarfında ilişkilerini çok yönlü ve olumlu açıda geliştirmiştir. İlişkilerin bir yönünün de askeri boyutlu olduğu, stratejik yönden tehdide açık bir dönem ve coğrafyada olan iki ülkenin bu doğrultuda da yakın münasebet sergilediği bilinmektedir. Askeri boyutlu ilişkiler içinde oldukça önemli yer tutan askeri kolluk kuvvetlerinin birlikteliği de iki ülkenin diplomasisinin gelişmeye başlamasından hemen sonra kendisini göstermiştir. Türkiye'nin, Karabağ'da yaşananlar üzerinden Azerbaycan'ın iç güvenlik, savunma, strateji belirleme gibi askeri konulardaki eksikliğinin fazlalığını fark etmesi ikili ilişkilerin bu yönde de hızla ilerleme kaydetmesini sağlamıştır. 


\section{Azerbaycan'ın Askeri Boyutlu Sorunları ve Türkiye'nin Tutumu}

İki ülke arasındaki ilişkilerin başlangıcı, Azerbaycan'ın kuruluşuna dayanmaktadır. 18 Ekim 1991'de bağımsızlığına kesin olarak kavuşan Azerbaycan (Saray, 2010: 181), 9 Kasım 1991 tarihinde Türkiye tarafından resmen tanınmış (Türkiye, Azerbaycan’ı Resmen Tanıdı, Cumhuriyet, 10 Kasım 1991; TBMM, 12 Aralık 1991: 570; Armaoğlu, 2005: 938), 25 May1s 1991'de aç1lan Türk Konsolosluğu, 14 Ocak 1992'de imzalanan diplomasi içerikli anlaşmanın ardından büyükelçilik ${ }^{3}$ haline getirilmiştir (Bilgin, 2016: 147-148). Moskova tarafından Azeri Komünist Partisi liderliğine getirilen Ayaz Muttalibov, 1990 Mayıs ayında Azeri Yüksek Sovyeti tarafından başkan seçilmiştir. Muttalibov'un 21 Aralık 1991'de Bağımsız Devletler Topluluğuna katılımı imzalaması ${ }^{4}$, Azerbaycan'ın Rusya ve Ermenistan ile beraber hareket ettiği gerekçesiyle milliyetçi kesim tarafindan tenkit edilmiştir. Aynı şekilde Şubat 1992'de Dağlık Karabağ'da Azeri sivillere Hocalı'da yapılan katliamda Muttalibov'un yetersiz kalması da Azeri Halk Cephesi tarafindan eleştirilmiştir. Her ne kadar 14 Mayıs 1992 tarihinde Dağlık Karabağ'daki yenilgi Muttalibov’un otoritesini iyice zayıflatsa da, Yüksek Sovyet, başkanlığının devamına karar vermiştir. Ancak Yüksek Sovyet Binasıyla başkanlık sarayının iki gün kuşatma altında kalması ile yönetim değişmiştir (Harp Akademileri Komutanlı̆̆1, 1993a: 2-3). ${ }^{5}$

Bahsedilen süreçte Azerbaycan'ın güçlü bir ordusu bulunmamaktadır ${ }^{6}$. Her ne kadar düzenli bir milis kuvveti yapılanmasına gidilmesi düşünülmüşse de Muttalibov'un kabul etmemesi nedeniyle gerçekleştirilememiştir. Dolayısıyla Karabağ’ daki çatışmalar için Halk Cephesi’nin desteğiyle bir güç

\footnotetext{
${ }^{2}$ Azerbaycan Cumhuriyeti'ni ilk tanıyan devlet Türkiye Cumhuriyeti olmuştur. Bkz. TBMM Tutanak Dergisi, Dönem: 19, C: 1, Birleşim: 16, 17 Aralık 1991, s. 629. Azerbaycan'da ilk büyükelçilik de Türkiye tarafindan açılmıș, daha doğrusu var olan başkonsolosluk büyükelçiliğe dönüștürülmüştür. Bkz. TBMM Tutanak Dergisi, Dönem: 19, C: 3, Birleşim: 29, 22 Ocak 1992, s. 83. Azerbaycan'da Bakü Büyükelçiliğinden ayrı Nahcivan ve Gence Başkonsoloslukları bulunmaktadır. Azerbaycan'ın ise Ankara Büyükelçiliğinden başka İstanbul ve Kars Başkonsoloslukları vardır. Bkz. Nesrin Sarıahmetoğlu, Okan Yeşilot, "Azerbaycan Cumhuriyeti", Bağımsızlıklarının 25. Yllında Türk Cumhuriyetleri, Edt. Abdulvahap Kara, Fahri Solak, Türk Dünyasi Belediyeler Birliği Yayınları, İstanbul 2017, ss. 7-72, s. 29.

3 İlk Bakü elçimiz Memduh Şevket Esendal (1920-1924) olup Azerbaycan Cumhuriyeti'ndeki Bakü Büyükelçimiz ise Altan Karamanoğlu (1992-1995)'dur. Bkz. BCA, Fon: 30.18.1.2. Kutu: 703. Gömlek: 268. Sıra: 4. "Bakü'de Coşku Var", Milliyet, 23 Ocak 1992, s. 17. http://baku.emb.mfa.gov.tr/Mission/MissionChiefHistory

${ }^{4}$ Rusya, Ukrayna, Beyaz Rusya, Moldavya, Kazakistan, Azerbaycan, Ermenistan, Özbekistan, Türkmenistan, Kırgızistan ve Tacikistan'ın katıldığı Alma Ata Toplantısında eski SSCB'ye bağlı 11 Cumhuriyetin lideri Bağımsız Devletler Topluluğunu kurmuştur. Bkz. "SSCB Resmen Yok Oldu”, Cumhuriyet, 22 Aralık 1991, s. 114.

5 “Azerbaycan Yüksek Sovyeti, 19 Mayls 1992'de kendini feshederek, tüm yetkilerini, adı değiştirilen ve Azerbaycan Cumhuriyeti'nin milli meclisi olan Milli Şuraya devretmiştir. Halk Cephesi milletvekillerinden İsa Kamberov, bu meclis tarafindan Cumhurbaşkanı vekili olarak seçilmiş ve göreve başlamıştır. Eski yönetimle şimdilik bir uzlaşma sağlandı̆̆ı söylenerek Başbakan eski yardımcısı Rahim Hüseyinov da Başbakanlık görevine getirilmiştir.” Bkz. TBMM Tutanak Dergisi, Dönem: 19, C: 11, Birleşim: 78, 20 Mayıs 1992, s. 204.

${ }^{6}$ Demirel'in Türk Cumhuriyetlerine gerçekleştirdiği geziden sonra TBMM'de yaptığı konuşmadaki şu sözleri bu bilgiyi destekler niteliktedir: “...Bu ülkelerin henüz hiç birisinde -Azerbaycan hariç-kendi kendilerini koruyacak güvenlik kuvveti falan da yoktur. Yani, bizi bando, mızıka, askerle falan karşıladılar; ama, oradaki eski Sovyet garnizonundan ödünç alınmış askerlerle karşıladılar!.. Henüz kendilerinin güvenlik kuvvetleri yok. Zaten altı ay içerisinde kendilerinin bir şeyi olabileceğini de farz etmek yanllş...” Bkz. TBMM Tutanak Dergisi, Dönem: 1, C: 10, Birleşim: 74, 7 Mayıs 1992, s. 414.
} 


\section{Selma GÖKTÜRK ÇETINKAYA}

oluşturulmuştur. Ancak bu yapı hem düzen sağlayamamış, hem de maddi destek alamadığından teçhizatta da zayıf kalmıştır ve Elçibey Dönemine değin Karabağ'ın kaderi Karabağlılara bırakılmıştır. (TBMM, 1993: 21). Öyle ki Karabağ'da yaşananların Azerbaycan'daki siyasi istikrarsızlı̆̆ın devamlılığına yol açtığı; iç bütünlük, güvenlik ve ortak strateji noktasında da sorunların çözülemediği; ayrıca her ne kadar 28 Şubat 1992'de Avrupa Güvenlik ve İşbirliği Konferansı'nın (AGİK) Prag toplantısında Karabağ Azerbaycan'ın bir parçası olarak tescil edilmişse de Karabağ’da askeri üstünlügün Ermenilere geçtiğgi ${ }^{7}$ bu dönemde Türkiye'den de okunmaktadır. Nitekim SHP İstanbul Milletvekili Algan Hacaloğlu, Azerbaycan'ın bu realitesinin 7 Haziran 1992'de yapılacak cumhurbaşkanlığı seçimlerine kadar da düzelemeyeceğini dile getirerek "Karabağ'ın silahlardan arındırılmasl, Karabağ'da askeri aktivitelerin durdurulmast, her iki taraftan mültecilerin Karabağ'a geri dönmesi, yıklan kentlerin onarılması için gerekli ekonomik desteğin, AGIK'in katkısıla dışarıdan sağlanması; bu çerçevede, Azerbaycan'ın, hukuken ve uluslararası kurallar çerçevesinde bir parçası olan Karabağ'da, kalıcı bir barışın zemini içinde, demokrasi açısından özgürlüklerin beşiği olacak din ve kültür özgürlüğünü tüm kesimlere tanlyacak ve içişlerinde, iç yönetiminde belirli bir otonomi altında; ama Azerbaycan'a bağlı bir yapı içinde, bölgede huzur getirecek siyasi bir çözümün sağlanması" içerikli hazırladıkları raporun AGİK'e sunulduğunu ifade etmiştir (TBMM, 14 Nisan 1992: 39-40). Bu süreçte Türkiye'nin Azerbaycan'da yaşananlara dair bağlı olduğu teşkilatların dikkatini çekmeye çalıştı̆̆ı ve onlar aracılığıyla Karabağ’ın huzur bulmasına çaba sarf ettiği söylenebilir. Bu tutumu nedeniyle DYP-SHP Koalisyon Hükümetinin muhalefetin tepkisini fazlasıyla çektiği de görülmektedir. Eş zamanlı olarak Azerbaycan'da ise yönetimde değişikliğe gidilmiş ve Ebulfez Elçibey dönemi başlamıştır.

Azerbaycan'da Muttalibov'dan sonra ilk olarak Prof. Yakup Memmedov vekaleten devlet başkanlığına getirilmiş, ardından 7 Haziran 1992 tarihli seçimle Ebulfez Elçibey idareyi ele almıştır (Elçibey Yemin Etti, Cumhuriyet, 17 Haziran 1992; Harp Akademileri Komutanlı̆̆1, 1993b: 23). Sovyet Rusya politikalaryyla uyumlu ve fakat halktan kopuk bir profil çizen Ayaz Muttalibov'un ardından 1992 senesinin haziran ayında cumhurbaşkanlığına seçilen Ebulfez Elçibey, stratejik hassasiyeti de göz önünde bulundurarak yönünü Türkiye’ye dönmüştür. Buradan hareketle Elçibey döneminde Türkiye ile diplomatik ilişkilerin geliştirildiği görülmektedir (Mardanov, 2013: 60; Aydın, 2018: 40). Diğer taraftan Halk Cephesi Başkanı Elçibey'in cumhurbaşkanlığı seçiminde Türkiye tarafından desteklendiği belirtilmelidir. Dönem basınında bu desteğe dair getirilen yorumda

\footnotetext{
${ }^{7}$ Askeri üstünlüğün Ermenilere geçmesi şaşılacak bir durum değildir. Rusya ve Batılı devletlerin desteğini alan Ermenilerin ve diğer Hıristiyanların SSCB Döneminde askeri işlevselliği vardır. Oysaki SSCB Döneminde Müslüman toplulukların askerleri (er ve rütbeli ayırt etmeksizin) muharip sınıflarda görevlendirilmemiş; geri hizmetlerde, destek hizmetlerinde, inşaat hizmetlerinde görevlendirilmişlerdir. Benzer durum Yugoslavya ordusunda da söz konusudur. Bkz. TBMM Tutanak Dergisi, Dönem: 19, C: 34, Birleşim: 92, 15 Nisan 1993, s. 205. Dolayısıyla savaş yetisine sahip olmayan Azerbaycan, savunmada kalmış ancak Ermeni ve Rus saldırılarına nasıl karşı koyacağını da bilememiştir. Bu durum da başarısızlıkları beraberinde getirmiștir. Ayrıca Azerbaycan ordusunun gerekli silah ve mühimmattan yoksun olması, taburların dağınık, disiplinden ve düzenden uzak bulunması, askeri operasyonların uyumsuzluğu, özel birliklerin azlığı, bazı askeri birliklerin siyaseten bağımlılığı da Azerbaycan'ı olumsuz etkilemiştir. Bkz. Sarıahmetoğlu, Yeşilot, s. 10.
} 
“Moskova'dan ne kadar ürküyorlarsa bize de o kadar güveniyorlar" ifadesi kayda değerdir (Hürriyet, 5 Mayıs 1992). Bu minval üzere Elçibey’in “Türkiye Azerbaycan'ın dış politikasının başköşesinde yer alacaktır” ifadesi de (Bilgin, 2016: 148) iki ülke arasındaki iyi ilişkilerin dayanak noktası olarak görülebilir. Nitekim yine Elçibey'in “Azerbaycan Türkiye için Türk alemine, aynı zamanda Doğu'ya, Türkiye ise Azerbaycan için Avrupa'ya ve Batı'ya açılan kapıdır" (Harp Akademileri Komutanlığı, 1993b: 12) sözlerinin de doğruluğu muhakkaktır. Azerbaycan'ın Türkiye ile münasebetini olumlu tuttuğu bu dönemde sınırlarının halen BDT Antlaşması kapsamında Rusya Federasyonu tarafindan korunduğunu da belirtmek gerekmektedir. İç güvenlikte ise milis olarak adlandırılan kır ve kent polisleri ve ayrıca trafik görevlileri ile sınırlı kalan Azerbaycan'da Halk Cephesinin ordu kurulmasına dair talepleri bu dönemde de devam etmiştir (TBMM, 1993, 20-21). Bundan ayrı Türkiye'deki emekli subayların bir kısmının Azerbaycan'a giderek askeri eğitim konusunda yardımcı olduklarını, Azerbaycan'dan gelen 200 öğrencinin de Türkiye'de askeri okullarda eğitildiğini söyleyebiliriz (Babayeva, 2013: 76).

Azerbaycan'da Ebülfez Elçibey'in bir isyan/darbe sonrası ${ }^{8}$ yerine geçen (Azerbaycan'da Aliyev Darbesi, Hürriyet, 19 Haziran 1993; Elçibey Krizi, Milliyet, 19 Haziran 1993) ve Elçibey’in başkanlığı döneminde Nahçıvan Yüksek Meclis Başkanlığı yapan (Harp Akademileri Komutanlığı, 1993a: 4), Haydar Aliyev'in cumhurbaşkanlığının ilk döneminde, izlemek durumunda kaldığı denge politikası Türkiye açısından şüphe uyandırmışsa da bir süre sonra "bir millet iki devlet" söyleminde bulunması, bu şüphenin yersizliğini kısa sürede göstermiştir (Aydın, 2018: 41). Esasen Muttalibov'un Rusya'ya, Elçibey'in ise Batı'ya ve bu bağlamda Türkiye'ye dönük diplomasi geliştirmesinin ardından Aliyev ile denge politikası başlamıştır (Yılmaz ve Sayın, 2013: 39). 20 Eylül 1994 tarihli Petrol Antlaşması, Azerbaycan'ın ekonomik ve siyasal bağlamda Batı'ya açılması ve Rusya'yı bir nebze de olsa kısıtlaması açısından mühimdir. Öte yandan anlaşmanın ardından Clinton ve Major'un Dağlık Karabağ ile ilgili açıklamaları Aliyev'in Batı'ya bakışında askeri yönün bulunduğunu da göstermektedir (Arslan,1994: 213). Diplomatik açıdan küresel ve bölgesel manada düşünülerek başlatılan ve Türkiye ile de geliştirilen bu politika, Haydar Aliyev'den sonra da devam etmiştir. Bundan ayrı önceki dönemden devralınan milli hissiyat politikaları Haydar Aliyev döneminde de varlığını sürdürmüş, aynı zamanda Türkiye'den giden subayların verdiği eğitimlerle Azerbaycan ordusu toparlanıp Ermeni işgalindeki toprakların kurtarılması sağlanmıştır (Azeri Şahlanışı, Hürriyet,

\footnotetext{
${ }^{8}$ Azerbaycan'daki gelişmelerle ilgili TBMM'de uzun tartışmalar yaşanmıştır. Özellikle Mesut Yılmaz ve Hikmet Çetin arasında yaşanan tartışmada Yılmaz’ın “Azerbaycan'ın bă̆ımsızlığını kazanmasından bugüne kadar geçen devrede, muhtelif aşamalarda, Türk Hükümeti, üstüne düşen görevi yerine getirmemiştir, Ermeni saldırısı karşısında Azerbaycan'a yardımcı olmamıştır. Türkiye'nin, Ermeni saldırısına uğrayan Azerbaycan'a her türlü yardımı askeri yardım, silah yardımı, lojistik yardım sağlamasına engel hiçbir uluslararası hukuk kuralı yoktur, bunu engelleyecek hiçbir husus yoktur; ama Ermeni saldırısı karşısında siz, Azerbaycan'ın sizden beklediği desteğin binde birini bile sağlamazsanız, Azerbaycan'ın bugün içine düştüğ̈̈ iç kaosta sizin de sorumluluğunuz olur ve ondan sonra, bu sorumluluğunuzu yerine getirememenin ezikliği içerisinde buraya gelip, işler bu safhaya geldikten sonra, sizin sorumluluğunuzla bu safhaya geldikten sonra, ellerinizi açar, 'ne yapabiliriz?' diye Meclise sorarsınız!’ sözleri muhalefetin genel bakışı olarak değerlendirilebilir. Bkz. TBMM Tutanak Dergisi, Dönem: 19, C: 37, Birleşim: 115, 22 Haziran 1993, s. 22-23
} 


\section{Selma GÖKTÜRK ÇETINKAYA}

15 Ocak 1994). Bununla ilgili olarak Aliyev, 9 Şubat 1994'te TBMM'de yaptığı konuşmada şu

ifadeleri kullanmıştır:

“...Bu devirde; yani, Azerbaycan Halkl, ilk demokratik devlet yarattığ bir devirde (1918), Türkiye, Azerbaycan ile yan yana olmuş, beraber olmuş, Türkiye'nin Azerbaycan'a çok yardımı, kömeği olmuştur. Bunu, Azerbaycan Halkı hiçbir vakit unutmamıştır ve unutmayacaktır. O vakit, Azerbaycan Halkı ayrı ayr düşmanlar tarafindan tecavüze kalmıştır. Türk Ordusunun Azerbaycan'a gelmesi, Bakü'ye gelmesi, Azerbaycan'l, o vakit, Ermeni Taşnaklarının tecavüzünden halas etmesi (kurtarması) her bir Azerbaycanlının kalbinde yaşıyor ve Azerbaycan halkı, Türk halkının, Azerbaycan'a o ă̆ır devirdeki kömeğini ve yardımını hiçbir vakit unutmayacaktır. Teessüf ki, bu devlet, sükûta gitmiştir. O vakit bütün geçmiş Rusya Imparatorluğunda Sovyetler Birliği yer almış, Azerbaycan, 70 yıl Sovyetler Birliği terkibinde olmuştur... Ben kaydettim ki, 1918'inci yllda ilk Azerbaycan Demokratik Cumhuriyeti yer aldığında da, Türkiye, ilk defa Azerbaycan'ı tanıyan devletlerden olupdur. Azerbaycan öz müstakilliği uğrunda mübareze aparırken (verirken) hele Sovyetler ittifakının terkibinde olduğu bir vakıtta, 1992 'nci yılın Noyabır (Kasım) ayında, Türkiye Cumhuriyeti, dünyada ilk devlettir ki, Azerbaycan'ın müstakilliğini tanımış ve Türkiye'nin bu cesaretli adımı, Azerbaycan'a gardaşlı münasebeti, Azerbaycan'ın müstakilliğini elde etmek için bütün dünya devletleri tarafindan Azerbaycan'ın tanınması için çok böyük köme (destek) olmuştur. Buna göre ve ondan sonra Azerbaycan'ın müstakilliginde Azerbaycan'a ettiğiniz yardımlara göre, Azerbaycan halkı adına ben sizlere teşekkür edirem. O vakıttan 2 yıl geçir. 2 yıl, o kadar böyük müddet değil. Bu 2 yll içerisinde Azerbaycan'ın başına çok belalar gelmiştir. Bir bu 2 yıl değil, ondan gabakk (evvelki) devirde de -bilirsiniz tahminen 1987'nci yılın sonunda, 1988'inci yılda Azerbaycan'ı parçalamak, dağıtmak niyetinde olan düşman kuvveler, Karabă̆ problemini ortaya atmışlar ve sürekli olarak Ermenistan'ın, Azerbaycan'a tecavüzü devam etmiştir. Bu devirde, biz, daima, Türkiye'nin tarafindan yardımlar almışık. Manevî yardım, devlet kuruculuğunda yardım, beynel halk âlemde yardım ve başka yardımlar ve bugün itiraf etmeliyem ki, teessüf ki, biz, Türkiye'nin, Azerbaycan'a, bu devirde gösterdiği gaygl ve münasetin karşısında lazımı tedbirler görebilmemişik ve olabiler ki, eğer bizim faaliyetimiz, bize gösterilen gaygl ve tedbirler seviyesinde olsayd, Azerbaycan'ın vaziyeti bugün bundan da yahşi (iyi) olardı. Ancak, bir şey hagigattir ki, 6 yıldır Azerbaycan muharebe şeraitindedir. Bu muharebe şeraitinde, Azerbaycan'ın içinde de çok böyük değişiklikler meydana gelmiştir. Bu müddette Azerbaycan'ın içerisinde, ayrı ayrı siyasî kuvveler tarafindan hâkimiyet mübarezesi getmiş, o hâkimiyet mübarezesi Azerbaycan'ın devletçiliğini zeyifletmiş, Azerbaycan'ın ordusunu, gurulmamış, yaranmamış ordusunu zeyifletmiş, müdafaa imkânlarını zeyifletmiş ve bunlardan istifade eden Ermeni Silahlı Kuvvetleri, Ermeni tecavüzkârları Azerbaycan'a devamlı hücumlarına devam etmiş ve bunun neticesinde, artık, Azerbaycan torpaklarının yüzde 20 faizi Ermeni Silahlı Kuvvelerinin işgali altındadır. Ĕger, başlangıç devrinde, sohbet Dă̆lık Karabağ'dan gedilse, indi artık Dă̆lık Karabă̆ tamamıyla Ermeni Silahl Kuvvelerinin, Ermenistan'in kontrolü altındadır. Ondan sonra, Dağlık Karabă̆ etrafinda olan rayonlar, (bölgeler) bildiğiniz kibi, Ermenistan'ın işgali altına geçiptir ve gaydettim ki, bir milyon Azerbaycanll, öz yerlerinden köçüp gaçgın vaziyetinde yaşlyorlar. Bunlar hamsi (hepsi) Azerbaycan'ın müstakilliğine, müstakil devlet kibi süratle inkişaf etmesine çok büyük manilikler türedir. Ancak biz, nikbin ehvadı ülkedeyik. Biz hesap edirik ki, bizim müstakilliğimiz ebedidir bu müstakilliği heç vakt, her berçle biz elden veremeyeceğiz ve Azerbaycan halkı daimi müstekillik yoluyla gidecek, demokratya yoluyla gidecek, millî azatlık yoluyla gidecektir. (Alkışlar) Bu bakımdan, Türkiye indiye gadar bize ettiği kardaşlık, dostluk gaygısı ve kömeğiyle (yardımıyla) beraber, bundan sonra da bizim yanımızdadır ve yanımızda olmalıdır ve bizim sizinlen, bir yerde bugün beraber olmamız, buna eyani sübuttur..." (TBMM, 2012: 87-90).

Haydar Aliyev'in 1997'de gerçekleştirdiği ziyaretinde de Türkiye'nin yardımlarından bahsettiği görülecektir: “...Böyük memnuniyet, minnettarlık hissiyle demek istirem ki, Azerbaycan'a Ermenistan tecavüzü başlayandan indiye kadar, Türkiye, Türkiye’nin halkl, Türkiye'nin devleti, Türkiye’nin Cumhuriyeti, hamisi Azerbaycan'ın yanındadırlar, Azerbaycan'la bir yerdedirler. Bizim derdimize siz hemşe şerihsiniz ve bu meseleyi tek dert gam çekmek değil, bu meseleden Azerbaycan’ı hılas etmek için, biz, Türkiye’nin desteğini, emeli yardımını daimi hissetmişik ve hissedirik...” (TBMM, 6 Mayıs 1997: 14). Aliyev'in Türkiye'den destek gördüğünü söylediği süreçte, yani Ermeni saldırılarının yaşandığı zaman diliminde iç politikada belki de en çok konuşulan mevzuunun Azerbaycan’a yardım edilmemesidir, bu farklılığın oldukça ilginç 
olduğu ifade edilmelidir. Diğer taraftan bugün de Azerbaycan Haydar Aliyev'in hislerini benimsemektedir. ${ }^{9}$

Haydar Aliyev'in on yıllık cumhurbaşkanlığının ardından yerine seçilen ve halen cumhurbaşkanlığı makamında bulunan oğlu İlham Aliyev döneminde devam ettirilen denge politikası daha da geliştirilmiştir. Bu kapsamda Azerbaycan, işbirliği çerçevesinde ve milli menfaatler gözetilerek, yine de tehditlerin varlı̆ğ unutulmadan geliştirdiği çok yönlü diplomasisinde Türkiye'yi ayrı bir yere oturtmuştur. Var olan manevi yakınlıktan ayrı; köprü vazifesinde olan Türkiye'nin Azerbaycan'ın uluslararası sahada tanınırlığını sağlamak, kuruluşunda yaşadığı yapısal problemlere çözüm bulmak ve Karabağ Savaşı'nın hasarlarını gidermek gibi bir misyona sahip olduğu da unutulmamalıdır (Yılmaz ve Sayın, 2013: 33, 36). Aynı şekilde Azerbaycan da Türkiye ile Türk dünyası arasında bir köprü işlevi görmektedir. Atatürk'ün 18 Ekim 1921 tarihinde Ankara'daki Azerbaycan Büyükelçiliğinde yaptığı konuşmada belirttiği gibi “Azerbaycan, Asya'daki kardeş hükümet ve milletler için bir temas ve kavuşma noktasıdır. Azerbaycan'ın bu mevki-i mahsusu, vazifesini pek mühim kllmaktadır" (TBMM, 4 Mart 1992: 590). Bu minval üzere karş11ıklı şekilde önem içeren iki ülke, 1992 y1lından itibaren devam eden süreçte genel manada iyi ilişkiler kurmuştur ki giderek gelişen bu diplomaside Türkiye ile Azerbaycan'ın özellikle stratejik ortaklığından bahsetmek mümkündür. Sahip olduğu doğalgaz ve petrol $^{10}$ nedeniyle global ve bölgesel güçlerin odağındaki Azerbaycan'ın Türkiye ile ilişkisinde ise aynı soydan geliyor olmaları ve tarihi münasebetleri belirleyici rol oynarken Nahçıvan ve Dağlık Karabağ ile Ermeni Meselesi de bu ilişkideki temel konular arasında yer almaktadır (Yalçınkaya, 2018: 573-577). Nitekim dönemin cumhurbaşkanı Turgut Özal, 1993'te Azerbaycan ziyareti ${ }^{11}$ esnasında Dağlık Karabağ sorununda Ermeniler savaşı durdurmadı̆̆ 1 takdirde ${ }^{12}$ Türkiye ile Azerbaycan arasında askeri ittifakın oluşturulmasının gerekliliğine vurgu yapmıştır (Özal, Bakü’ye Askeri İttifak Önerdi, Cumhuriyet, 15 Nisan 1993: 1-17). Bu konuşmanın iç politikadaki çok sesliliği susturmaya yönelik olduğu da söylenebilir. Öte yandan bu geziden dönüşünün ertesi günü

\footnotetext{
9 "Türkiyə Azərbaycanın beynəlxalq səviyyədə tanınan ərazi bütövlüyünü və Ermənistanın tarixi arazilarimizin işğalı nəticəsində yaranmuş münaqişadə Azərbaycanın ədalatli mövqeyini hər zaman müdafiə edir va iki ölkə arasinda beynalxalq arenada qarşlliql dəstək ənənəsi davam etdirilir." Bkz. http://www.mfa.gov.az/az/content/151/turkiye

${ }^{10}$ İlham Aliyev'in "asrın kontratı" dediği ve Özal Dönemi itibariyle planlamaları yapılan Bakü-Ceyhan Boru Hattının temeli 2002'de atılmıştır. Bkz. "Rüya Gerçek Oldu”, Hürriyet, 19 Eylül 2002, s. 1-11.

${ }^{11} 27$ Nisan-4 Mayıs 1992 tarihleri arasında da başbakan Süleyman Demirel Özbekistan, Kırgızistan, Kazakistan, Tacikistan, Türkmenistan ve Azerbaycan'a ziyaret gerçekleştirmiştir. Beraberinde giden heyette Mahmut Öztürk (Aksaray), Hasan Çakır (Antalya), Bahattin Alagöz (Gaziantep), Mehmet Dönen (Hatay ),Halit Dumankaya (İstanbul), H. Hüsamettin Özkan (İstanbul), Ömer Ekinci (Ankara), Oktay Öztürk (Erzurum), Ayvaz Gökdemir (Gaziantep), Bedrettin Dalan (İstanbul), İ. Safa Giray (İstanbul), Abdülkerim Doğru (Kars), A. Münif İslamoğlu (Kastamonu), İ. Hakkı Amasyalı (Kocaeli), Abdüllatif Şener (Sivas), Seyfi Şahin (Kayseri), Muzaffer Arıkan (Mardin), Hüseyin Erdal (Yozgat), Alparslan Türkeş (Yozgat) vardır. 19 milletvekilinin altısı Doğru Yol Partisi'nden, üçü Sosyal demokrat Halkçı Parti'den, üçü Anavatan Partisi'nden, üçü Refah Partisi'nden, üçü Milliyetçi Çalışma Partisi'nden ve biri de Demokratik Sol Parti'dendir. Bkz. TBMM Tutanak Dergisi, Dönem: 19, C: 9, Birleşim: 69, 28 Nisan 1992, s. 385-386.

${ }^{12}$ Karabağ Savaşının hücum ve savunma planları Moskova'da hazırlandığına dair ayrıntılı bilgi için bkz. Yasin Arslan, "Azerbaycan Bilmecesi, Petrol, Darbeler ve Gerçekler", Avrasya Dosyası, Kış 1994, S. 95, C. 1, 211 218, s. 212.
} 


\section{Selma GÖKTÜRK ÇETINKAYA}

Cumhurbaşkanı Turgut Özal'ın hayatını kaybetmesi iç politikanın seyrini belli bir süreliğine değiştirecektir.

1992’nin başına dönecek olursak, Karabağ olayları kapsamında konuşan DSP Zonguldak Milletvekili Bülent Ecevit “Azerbaycan'a insani yardımın yanı sıra, her türlü askeri araç ve gereç yardımını da yapmalıdır. Türkiye, savaşa katılmaksınız, bu ülke yönetiminin, Azerbaycan yönetiminin gereksinme duyabileceği askeri eğitimi de sağlamalıdı" (TBMM, 4 Mart 1992: 589) cümleleriyle askeri eğitim ve teçhizat yardımının önemine dikkat çekmiştir. Benzer şekilde RP Konya Milletvekili Necmettin Erbakan da Azerbaycan'a hem ekonomik hem de askeri yardımın yapılması gerekliliğine dair açıklamalarda bulunmuş ve bu gerekliliğin aksiyon planında mutlak suretle yer almasını istemiştir (TBMM, 10 Mart 1992: 50). Ancak dönemin başbakanı Süleyman Demirel ${ }^{13}$, bu görüşlere cevaben Azerbaycan'ın Karabağ sorununu barış yoluyla çözmek istediğini söyleyerek Türkiye'den askeri yönde desteğin olmamasının nedenine açıklama getirmiştir. (TBMM, 10 Mart 1992: 135). Yine de sonraki günlerde de Mecliste benzer taleplerde bulunulduğunu görmekteyiz. Örneğin Demirel'in konuşmasından dokuz gün sonra RP Kayseri Milletvekili Aykut Edibali, "Karabağ’n muhtariyetinin her türlü sulhçu veya askeri güç kullanarak çözülmesine kararlı olduğumuz gösterilmelidir. Ülkemiz, bir Hatay ve Kıbrıs kararlılığını beklemektedir” ş̧eklinde görüş bildirmiştir (TBMM, 19 Mart 1992: 390). Bu süreçte Ermenistan'dan da Türkiye'nin askeri müdahalesine yönelik tehditkâr söylemler gündeme geldiğini belirtelim. Nitekim Ermeni Dışş̧̧eri Bakanı Rafi Hovanisyan, Türkiye’nin Karabağ’a askeri müdahalede bulunması halinde bölgesel savaşın çıkabileceğini ifade etmiştir (Erivan'dan Bakü'ye Savaş Sinyalleri, Cumhuriyet, 20 Mart 1992: 1-19). Ayrıca Azerbaycan Başbakanı Hasan Hasanov'un Ankara'ya gönderdiği mektupta Türkiye'den asker istemediğini de Demirel'in gazetecilerin sorularına verdiği cevaplar arasında görebilmekteyiz ${ }^{14}$. Aynı tarihli gazetede Ankara'daki Batılı diplomatların Türkiye'nin Azerbaycan'a silah yahut askeri yardım göndermeye dayalı bir hazırlığının olmadığını içeren bir haber de bulunmaktadır (Azerbaycan'a Yardım Yok, Cumhuriyet, 20 Mart 1992: 11).

Bu haberin ardından muhalefetin askeri desteğin yapılmamasına dair eleştirilerinin arttığını TBMM tutanaklarında görmek mümkündür. Bu eleştirilere yanıt verenlerden birisi de DYP Adana Milletvekili Uğur Aksöz olmuştur ve ulusal hukuk kapsamında Azerbaycan'a gereken desteğin verildiğini, uluslararası hukukun ise dışına çıkılamayacağını, dünya devletlerine ve milletlerine karşı sorumlu

\footnotetext{
13 Süleyman Demirel'in konuşmasında muhalefetin tenkitlerine verdiği yanıt oldukça düşündürücüdür: “...Azerbaycan işini kimse istismara kalkmasın. Rus tankları Azerbaycan'da 800 kişinin hayatına kastettiği zaman, Türkiye'de yüksek yerlerden ses çıtkt. Burada gazete kupürleri de var, ses şöyle çıktı: "Zaten onlar bizim mezhebimizden değildir" biçiminde. Şimdi bunları unutup da, buraya gelip gecenin bu saatinde Azerbaycan kahramanlığ yapmanın anlamı yoktur; eğri oturalım, doğru konuşalım...” Bkz. TBMM Tutanak Dergisi, Dönem: 19, C: 5, Birleşim: 46, 10 Mart 1992, s. 137. Demirel'in Turgut Özal'ın 1992'de ABD'de “onlar Şii, Türkiye'den ziyade Iran'a yakın... Biz Sünniyiz" sözlerine gönderme yaptığı görülmektedir ki bu konu daha sonra da Meclis'e taşınmıştır. Bkz. TBMM Tutanak Dergisi, Dönem: 19, C: 7, Birleşim: 54, 18 Mart 1992, s. 274. TBMM Tutanak Dergisi, Dönem: 19, C: 7, Birleşim: 55, 19 Mart 1992, s. 353.

${ }^{14}$ Hasanov'un yardım talep eden mektubundan Dışişleri Bakanı Hikmet Çetin'in haberinin olmadığına dair ANAP Rize Milletvekili Mesut Yılmaz'ın konuşması için bkz. TBMM Tutanak Dergisi, Dönem: 19, C: 8, Birleşim: 61, 25 Mart 1992, s. 628.
} 
olunulduğunu söyleyerek bu konuya açıklı getirmiştir (TBMM, 25 Mart 1992: 602). Aynı oturumda MÇP Yozgat Milletvekili Alparslan Türkeş ise dünyadaki tüm Türklerle ilgilenilmesi ve meselelerinin çözümlenmesi gerekliliği, bunun için de Türk Dünyası Bakanlığı’nın kurulmasının zarureti üzerinde durmuştur (TBMM, 25 Mart 1992: 665). Türkeş’in bir diğer talebi de Yüksek Türk Cumhuriyetleri Konseyi'nin kurulması yönündedir. ${ }^{15}$ Buradan hareketle "Türkiye'nin stratejik konumu, genis topraklara yayılan Türk devletleri arasında bir Türk birliği fikri yaratarak gelecekte büyük bir güç olarak ortaya çımasına müsaittir" (Sarıhmetoğlu, 2011: 165-166) cümlesi üzerinde durmak gerekir. İlerleyen dönemde samimiyet çerçevesinde pek çok sahada görülen Türkiye-Azerbaycan ilişkilerinin özellikle ekonomi ve enerji kapsamında derinleştiğini söylemek yerinde olacaktır. Böyle olmakla beraber asıl önemli olan elbette stratejik ortaklık olmalıdır. Bu nedenle güvenlik konusundaki ilişkilerin ve bu yönde yaşanan gelişmelerin de üzerinde özellikle durmak gerekmektedir. Coğrafi yönden zorlu bir yerde bulunan Türkiye ve Azerbaycan bu bilinçle jeopolitik, jeoekonomik ve jeostratejik hareketliliklerinde güçlü durabilmek ve küreselleşme noktasında da hasar almamak adına genel çerçevede birlikte görülmelidir. Esasen Karabağ’a karşı takınılan tutum da bu kapsamda hem eleştirilmiş, hem de savunulmuştur.

Karabăg'da yaşananları Türkiye, siyasal bağlamda yoğun bir şekilde gündeminde tutmuştur. Muhalefetin bölgeye yetersiz ilgi gösterildiğine ve askeri yardımda bulunulmadığına dair tenkitleri, iktidar tarafından görmezden gelinmeyerek yanıtlanmıştır. Örnek olması açısından DSP Genel Başkanı Zonguldak milletvekili Bülent Ecevit'in yedi maddelik soru önergesinin askeri destekle ilgili kısmı ile Dışişleri Bakanı Hikmet Çetin'in cevapları şu şekilde verilebilir:

“2. Batılı bazı ülkelerin Ermenistan'a, askeri araç ve gereç dahil, her türlü yardımı, Türkiye'nin hava ve kara sahasindan ve limanlarindan yararlanilarak gönderilmektedir. Bu yardimlarla Ermenistan'in saldirganlığ ve Azerbaycan Türklerine karşı zalimce soykırımı, Türkiye bir köprü gibi kullanılarak, etkin biçimde desteklenip özendirilmiş olmaktadır. Bu durumda, 28 Şubat günü AGiK çerçevesinde alınan Prag kararlarina tam olarak uyuluncaya ve Karabağ' in işgaline son verilinceye kadar, Ermenistan'a Türkiye üzerinden her türlü sevkiyatı ve ulaşımı durdurmayı ve Ermenistan'la sınırımızı kesin biçimde kapatmayı düşünӥуоr тиsunuz?

3. Ermenistan'in, dış destekle, düzenli birliklerle ve gelişmiş silahlarla Karabağ'a yönelttiği ve Prag kararlarına karşın sürdürdüğ̈̈ saldırılar karşısında, bağımsızlı̆̆ına yeni kavuşan Azerbaycan'ın, askeri donanım ve hazırllk bakımindan son derecede yetersiz kaldığı bellidir. Bu durumda Türkiye Azerbaycan'a, Ermenistan'in saldırısına karşı kendini savunabilmesi için gerekli askeri araç ve gereç yardımı ve savunma eğitimi desteği önermiş midir veya önerecek midir?

\footnotetext{
15 "Bağımsızlık almış olan Türk Cumhuriyetleriyle Türkiye, organik teşkilatlanmaya gitmelidir. Bu teşkilatlanma nasıl olabilir? Bunu, Türk cumhuriyetlerine yaptığımız ziyaretler sırasında onların yetkililerine de anlatmıştım. Şöyle bir çözüm sunabiliriz: Bağımsızlık almış olan Türk Cumhuriyetlerinin cumhurbaşkanları, başbakanları ve dıșişleri bakanlarının katılımıyla, bir "Yüksek Türk Cumhuriyetleri Konsey" meydana getirmek... Bu Konseye, alfabe sırasına göre, her cumhuriyetin cumhurbaşkanı, birer yll süreyle başkanlık eder. Alfabe sirasina göre Azerbaycan baş̧a geliyor, Azerbaycan Cumhurbaşkanı bir yll başkanlık eder; ondan sonra Kazakistan geliyor, Kazakistan Cumhurbaşkanı; sırayla, bu şekilde başkanlık ederler, ihtiyaç gördükleri kadar ve çeşitli yerlerde toplantılarını düzenleyebilirler, bir araya gelebilirler. Bunların altında da, her cumhuriyetten 25 uzmandan meydana gelen, 25 uzmanın katılmaslyla bir 'Türk Cumhuriyetleri İşbirliği Daimi Meclisi' teşkil edilebilir. Böylece, bu cumhuriyetler arasında ekonomik işbirliği, kültür işbirliği gibi, her yönden slkı bir dayanışma, safha safha kurulabilir, meydana getirilebilir. Bu, Türkiye'mizin de gücünü artırır, o cumhuriyetlerin de gücünü artırır...” Bkz. TBMM Tutanak Dergisi, Dönem: 19, C:16, Birleşim: 94, 25 Ağustos 1992, s. 112.
} 
2. Ülkemiz ile Ermenistan arasındaki Markara Sınır Kapısı esasen kapalı durumdadır. Halihazırda bu kapıdan istisnai koşullarda ve sadece insani amaçlı ilaç ve gıda maddelerinin geçişine izin verilmektedir. Kapı bunun dışındaki tüm geçişlere kapalıdır. Söz konusu sınır kapısının açılması, belirli koşulların sağlanmasından sonra Ermenistan ile ülkemiz arasında diplomatik ilişki kurulmasından sonra mümkün olabilecektir. Öte yandan, AGIK/KMK'nın 28 Şubat tarihli kararında belirtilen silah ambargosunun uygulanması için hükümetimizce, hava sahamızdan bölgeye doğru uçan tüm kargo uçaklarının yüklerinin kontrol edileceği ve bu amaçla uçakların havaalanlarımızdan birine teknik iniş yapmasının isteneceği açıklanmış ve bu doğrultuda hareket edilmeye başlanmıştır. Aynı denetim bölgeye karayolundan yapılan sevkiyatta da uygulanmaktadır.

3. AGIKK/KMK'nın 28 Şubat tarihli kararı uyarınca taraflara silah ambargosu uygulanması için Hükümetimizce yoğun çaba gösterildiği ve bu yönde çeşitli kararların alındı̆̆ bir dönemde, Azerbaycan'a askeri araç gereç yardımı yapılarak söz konusu ambargonun tarafımızdan delinmesi, yukarıda belirtilen tutumumuzla çelişir ve bazı üçüncü ülkelerin Ermenistan'a açık ve yoğun bir şekilde silah yardımı yapmaları için mazeret olarak kullanılabilir.” (TBMM, 21 Nisan 1992: 311-314).

Hükümetin yanıtlarının tatmin edici olmadığını sonraki görüşmelerde eleştirilerin ve askeri yardım taleplerinin devam etmesinden anlamaktayı. Nitekim RP Malatya Milletvekili Oğuzhan Asiltürk Karabağ'daki Ermenilerin elinde Fransız, Amerikan ${ }^{16}$, Avrupa silahlarının bulunduğunu, kendilerinden yana olan topluluklara Batı ülkelerinin silah verdiğini, Türkiye'nin ise yaşananları AGİK'e şikayet etmekle yetindiğini, savaşa girmek zorunda olmadığımızı ama silah yardımı yapmak zorunda olduğumuzu, silah dahil her türlü yardımın yapılmasının zaruretini ${ }^{17}$ dile getirmiştir (TBMM, 7 Mayıs 1992: 482-483). Karabağ için Türkiye’nin askeri desteği noktasında değerlendirilmeli midir tartışılır ancak Azerbaycan Cumhurbaşkanı Ebulfez Elçibey'in 26 Haziran 1992'de TBMM'de yaptı̆̆ konuşmasını bitirirken kurduğu cümleler oldukça manidardır: “...Eğer biz de özgür olursak, bu

\footnotetext{
${ }^{16}$ RP Kocaeli Milletvekili Şevket Kazan'ın sözleri bu bağlamdadır: “...Amerika Birleşik Devletleri Erivan'da bir hastane yaptı, diğerini de yapıyor; Azerbaycan'a petrol için bask yapmaya başladı. Şimdi de Avacs uçaklarıyla, Azerilere karşı savaşan Ermeni kuvvetlerini takviye etmek için, yine Amerika desteği Ermenilerin arkasında!.. Işsin üzülünecek tarafi, Batı bunlar yaparken, Türkiye'yi de kullandl. Azerbaycan'da hem soy hem din kardeşlerimizin maruz kaldı $\breve{l}$ bu felaket karşısında biz, Türkiye olarak ne yapabilirdik?.. En başta ekonomik ambargo uygulayabilirdik; ama uygulamadık. Diplomatik ilişkilerimizi kesebilirdik, kesmedik; tam tersine, güçlendirdik. Azeri kardeşlerimize, Nahcivan'daki kardeşlerimize askeri teçhizat gönderebilirdik; ama göndermedik. Sesler yükseldi, 'Hiç değilse bir Türk Bayră̆ı gönderin' denildi de, bu çağrlya bile să̆ır kaldık, cevap vermedik. Askeri müdahalede bulunabilirdik, bulunmadik; hem de özellikle Nahcivan'da askeri müdahaleye hakkımı bulunduğu halde (Moskova Antlaşma'nın üçüncü maddesinden bahsedilmekte) müdahalede bulunmadık. Bu konuda iktidar partisinin yetkilileri, günlerce, 'Müdahaleye hakkımız yok' dediler...” RP'li Asiltürk ve Kazan'ın “Ermenistan ile milli menfaatlerimize zarar verecek şekilde bir politika izleyen hükümet hakkında gensoru açılması taleplerinde de benzer konuya değindikleri görülmektedir: “...Batı, aynı inancı paylaştı̆̆ Ermenistan'ı ve Gürcistan'ı desteklerken; Türkiye, İslam inancinı paylaştı̆̆ halde, ne Azerbaycan'a ne Yukarl Karabağ'a ne de Nahcivan'a hiçbir fiili ve askeri destekte bulunmamıştır. O kadar ki, Türkiye ile Rusya arasında imzalanan 1920 Moskova Anlaşması Türkiye'ye Nahcivan' l himaye hakkı tanıdı̆̆ ve Nahcivan'dan israrla askeri destek istendiği halde, Türk Hükümeti bu vecibeyi yerine getirmemiştir... Netice olarak "1. Milletimizin menfaatlerini korumakta aciz kalan, 2. Askeri müdahalede bulunmayacağız diye, caydırıcılık imkanını sıfıra indirerek Ermenistan'a meydanı boş bırakan, 3. Ermenistan'a ekonomik ambargo koymaya bile cesaret edemeyen, 4. Bütün bunlara ilaveten Ermenistan'la diplomatik münasebetleri kesme yerine, bu münasebetleri güçlendirdikten başka 100 bin ton da buğday yardımı yapan, 5. Aynı yardımı, Abhazya'daki Müslümanlarl yok etmeye kararlı Gürcistan'a da taahhüt eden, 6. Bu davranışlartyla Orta Asya Cumhuriyetleri nezdinde itibarımızı koruyamayan, Süleyman Demirel Başkanlı̆̆ındaki DYP-SHP Koalisyon Hükümeti hakkında Anayasanın 99 ve İçtüzügüun 107 nci maddesi gereği gensoru açılmasını talep etmek zaruret halini almıştır” Bkz. TBMM Tutanak Dergisi, Dönem: 19, C: 20, Birleşim: 21, 3 Kasım 1992, s. 19-21, 28.

172 Nisan 1993'te başlayan Kelbecer'in işgalinde de yardım konusu gündeme gelmiştir. Elçibey'in sivil insanların kurtarılması için istediği helikopterleri Türkiye vermemiştir. Bkz. https://www.youtube.com/watch?v=5G7qRrekx-k, TBMM Tutanak Dergisi, Dönem: 19, C: 34, Birleşim: 92, 15 Nisan 1993, s. 216.
} 
özgürlüğ̈̈müzde teç dayantp durmayacağız, özgür olmak uğrunda mücadele yapan bütün Türk Müselman dünyasina elimizden geleni edeceğiz, bir asker gibi onlara koşacağız...” (TBMM, 26 Haziran 1992: 178).

Azerbaycan'a bu süreçte Karabağ noktasında askeri yönden destek olunmadığı ortadadır. Öte yandan yaşananların Türkiye'nin güvenliği açısından da tehdit içerdiği unutulmamalıdır. Nitekim bu süreçte hem Ermenilerin Türkiye-Ermenistan sınırını tanımadıklarına dair söylemleri söz konusudur hem de PKK-ASALA işbirliği devam etmekte ve Türkiye'nin doğusunda terör artmaktadır (TBMM, 28 Ağustos 1992: 277, 310; TBMM, 16 Eylül 1992: 113). Üstelik Manisa Milletvekili Tevfik Diker'in ifade ettiği üzere "1974 Klbrls askeri müdahalesinin uluslararası forumlarda diplomatik müzakereleri hala sürerken, Kuzey Irak'taki sinır ötesi müdahalelerimiz dünya kamuoyunda yankilanmaya devam ederken, bunlara, zamanı ve koşulları iyi hesaplanmamış bir harekatla Nahcivan topraklarına girmemiz eklenirse, saldırgan bir ülke olarak nitelendirileceğimiz aşikardır" Dolayısıyla Türkiye'nin alacağ1 tutum; toprak işgaline seyirci kalmamakla beraber, barışçı yolları sonuna kadar zorlamak, netice alınamazsa ve müdahale kaçınılmaz hale gelirse orduyu harekete geçirmek şeklinde çizilmiştir (TBMM, 22 Eylül 1992:231). Ancak planın son ayağına yani orduyu harekete geçirme kısmına geçilmemiştir. Nitekim 2009 tarihli BM Genel Sekreterliği raporlarında Türkiye'nin BM kararlarına uygun hareket ederek resmi ya da sivil olarak işgal altındaki topraklarda faaliyet göstermediği belirtilmiştir. Rapora göre Türkiye, Dağlık Karabağ sorununun Güney Kafkasya'da barışın ve istikrarın inşa edilmesini önleyen faktör olarak görmektedir (Ministry of Foreign Affairs of the Republic of Azerbaijan Department for Analysis and Strategic Studies, 2017: 37). Türkiye'nin yeni sorunların doğmaması ve var olanların artmaması adına takındığı ve dışarıdan da gözlemlenen bu politik duruşun muhalefet tarafindan eleştirildiği muhakkaktır. Ancak milli güvenlik noktasının önce sınırlar dahilinde, akabinde sınırın ötesinde düşünüldüğü gerçekliği de göz ardı edilmemelidir ve bu gerçeklik sadece Türkiye için de geçerli değildir.

Dünya üzerindeki en problemli yerler arasında olan Kafkasya'nın da, bölge dışı güçler tarafından şekillendirilen politikalarından negatif etkilenmemek amacıyla milli güvenlik konusuna daha çok dikkat etmesi gerekmektedir (Sarıhmetoğlu, 2011: 191). Biraz daha genelleştirerek alanı Avrasya olarak görecek olursak, bu coğrafyanın öncelikle enerji sahası ve aslında genel manada var olan önemi; Rusya, $A B D$, Çin, $A B$ ve İran başta olmak üzere küresel ve bölgesel güçlerin nüfuz mücadelesini beraberinde getirmektedir (Haydaroğlu, 2018: 601). Buradan hareketle bu mücadeleden etkilenmemek yahut etkiyi azaltmak adına tehdide açık ülkelerin birlikte hareket etmesi gerekmektedir. Bu ortak hareket, jeostratejik yönden sadece dışarıya karşı bir savunma mekanizması oluşturmakla kalınmayıp iç güvenliğin de güçlendirilmesini içermelidir. Nitekim kuruluş sürecinde Azerbaycan'da var olan ve dağınıklığa neden olan farklı grupların çokluğu (TBMM, 19 Mart 1992: $383)$ iç güvenlik problemlerine yol açabilecek mahiyettedir ve böylesi problemlerin önlenmesi gerekmektedir. 


\section{Selma GÖKTÜRK ÇETINKAYA}

Bu gereklilikten yola çıkarak Türkiye, henüz kurulmuş olan Azerbaycan'ın iç güvenlik açısından desteklenmesi görevini 1992 itibariyle üstlenmiştir. 1992'nin nisan ayında sadece Azerbaycan değil, Kırgızistan, Kazakistan, Özbekistan ve Türkmenistan'ın devlet başkanlarıyla da görüşen dönemin başbakanı Süleyman Demirel (BCA, Fon: 30.18.1.2. Kutu: 714. Gömlek: 312. Sıra: 10); ekonomi, eğitim, kültür ve ulaşım başta olmak üzere neredeyse her sahada işbirliği içerikli anlaşmalar imzalamıştır. Aynı yılın ekim ayında ise Ankara'da ilk Türk Devletleri zirvesi gerçekleştirilmiştir. Cumhurbaşkanı Turgut Özal'ın ev sahipliğinde Türkiye, Azerbaycan, Kırgızistan, Kazakistan, Özbekistan ve Türkmenistan cumhurbaşkanlarının imzaladığı ortak deklarasyonla her alanda işbirliği yapılacağına dair bir önceki karar tekrar imza edilmişstir (Saray, 2003: 123-124). ANAP Bitlis Milletvekili Kamran İnan'1n ifadesiyle “Orta Asya'daki Cumhuriyetlerin güvendikleri bir kutup olan Türkiye'den başka bölgede ekonomik, teknolojik, sanayi ve askeri bakımdan bir güç yoktur" (TBMM, 18 Aralık 1991: 69). Bu nedenle doksanların başında Türkiye bölgesel olarak Türk devletlerini destekleyen mahiyette bir rol üstlenmiştir.

Türkiye'nin öncülük ettiği ortak hareket etmeye dair bölgesel politikalardan ayrı Azerbaycan ile ikili ilişkiler de yine her sahada olmak üzere uygulanmıştır ve uygulanagelmektedir. 24 Ocak 1992 tarihli Dostluk, İşbirliği ve iyi Komşuluk Anlaşması'ndan (TBMM, 17 Kasım 1992: 470) ayrı 1-5 Kasım 1992 tarihleri arasında Ebulfez Elçibey'in Türkiye'yi ilk resmi ziyaretinde gerçekleştirilen Azerbaycan Büyükelçiliğinin resmi açılışı ile beraber 15 siyasi belge de karşılıklı imza edilmiştir. $\mathrm{Bu}$ belgeler arasında en mühimi ise İşbirliği ve Dayanışma Anlaşması olmuştur (Azerbaycan ile İlişkiler Geliştirildi, Cumhuriyet, 2 Kasım 1992; Harp Akademileri Komutanlı̆̆ı, 1993b: 25). Ayrıca bu ziyaret esnasında ekonomik ve teknik içerikli çeşitli belgelerden ibaret 250 milyon ABD dolarlık bir kredi anlaşması da imza edilmiştir (TBMM, 17 Kasım 1992: 470). Esasen kuruluşundan kısa bir süre sonra Türkiye ve Azerbaycan arasında başlayan ilişkileri askeri sahada da görebilmek mümkündür ${ }^{18}$ ve bu doğrultuda ilk olarak 1992 senesinde iki ülke arasında anlaşma yapılmıştır. Aşağıdaki bölümde ayrıntıları verileceği üzere bu anlaşmanın gereği olarak 1994 yılı itibariyle Azerbaycan iç güvenliğini sağlayacak askeri statüdeki kolluk kuvvetlerinin eğitimine başlanmıştır. Bu eğitimlerin bir kısmı Türkiye'den gönderilen jandarma personeli tarafından Azerbaycan'da verilirken Türkiye'de verilen eğitimler de olmuştur. Ayrıca Jandarma Genel Komutanlığı ve Dahili Koşunlar Komutanlığı arasında gerçekleşen karşılıklı ziyaretlerle de iki ülkenin iç güvenlik teşkilatlarının arasındaki iletişim sağlamlaştırılmıştır. Böylece küresel tehditlere açık bir bölgenin iki kardeş devleti, milli güvenlik noktasında ilişkilerini geliştirmiştir.

\footnotetext{
188 Ekim 1992'de dönemin Milli Savunma Bakanı Nevzat Ayaz, Silahlı Kuvvetler Gününe katılmak için Azerbaycan'a gitmiştir. Bkz. TBMM Tutanak Dergisi, Dönem: 19, C: 19, Birleşim: 14, 13 Ekim 1992, s. 11-12.
} 


\section{Azerbaycan Dahili Koşunlar Komutanlığı'nın Kurulması ve Jandarma Genel Komutanlığı} ile İlişkileri

6 Eylül 1991 tarihinde Savunma Bakanlığı'nı kurmuş olan Azerbaycan, milli bir ordunun teşekkülüne ise hemen gitmemiş, önceleri Azerbaycan Halk Cephesi ve gönüllülerle yetinilmiştir. Ancak Ebulfez Elçibey, Ağustos 1992'de milli ordu için çalışmalara başlamış; Azerbaycan milli ordusunun yarısının gönüllülerden, yarısının ise zorunlu askere alınanlardan meydana geleceğini açıklamıştır (Harp Akademileri Komutanlığ1, 1993a: 7). "Kafkasya'nın kilit ülkesi Azerbaycan" (Yalçınkaya, 2018: 573) ile Türkiye arasında ilk olarak 11 Ağustos $1992^{19}$ tarihinde beş yıl süreliğine (eğer bitimine üç ay kala feshi istenmezse devam etmek üzere) Askeri Eğitim İşbirliği Anlaşması imzalanmıştır ki bu anlaşmayı TBMM yaklaşık sekiz ay sonra ${ }^{20}$ onaylamıştır (Resmi Gazete, Türkiye Cumhuriyeti Hükümeti ile Azerbaycan Cumhuriyeti Hükümeti Arasında Askeri Eğitim İşbirliği Anlaşmasının Onaylanmasının Uygun Bulunduğuna Dair Kanun, 21 Nisan 1993: 1). Anlaşmanın imzalanmasından önce Meclis’te konuyla ilgili görüşmeler de yaşanmış, SHP Ankara Milletvekili Ali Dinçer'in de belirttiği üzere tüm eğitim kurumları gibi askeri okulların da öğrenci ve araştırmacılara açılması gerekliliği üzerinde durulmuştur. Savunma gereksinimlerinin doğacak olması, savunma teşkilatlanmasına gidecek olmaları nedeniyle de Türkiye'nin nitelikli insan yetiştirme noktasında destek vermesi elzemdir (TBMM, 12 Aralık 1991: 575).

Onay tarihinden önce de TBMM'de görüşülen Askeri Eğitim İşbirliği Anlaşması için ANAP Ankara Milletvekili Vehbi Dinçerler “Ermenilerin, öz Azerbaycan, münakaşasız Azerbaycan topraklarında Karabağ 'ın dışında- kendilerine yakın olan topraklarda, üç tane koridor açma durumunda oldukları bu bölgede, onların, askeri güce, desteğe en çok muhtaç oldukları bir zamanda aslında düşünülmesi gereken, askeri eğitim anlaşması değil, onun çok daha ötesinde, mesela bizim Amerika Birleşik Devletleriyle yaptı̆̆ımı gibi, savunma işbirliği anlaşmasıdır. Nerede savunma işbirliği anlaşmast? Bunun da düşünüldüğünün ve yürütülmekte olduğunun bilgisi bende yok. İnşallah vardır; ama, her halükârda, savunma işbirliği anlaşmasına giden yolların açılması gerekir. Aksi halde, yalnı Hükümeti değil, bu millet, bu Parlamentoyu affetmeyecektir" demiştir.

\footnotetext{
${ }^{19}$ Nahçıvan Özerk Cumhuriyeti Ali Meclis Başkanı Haydar Aliyev'in Ankara ziyareti esnasında da 24 Mart 1992'de Türkiye ile Azerbaycan'a bağlı Nahçıvan Özerk Cumhuriyeti arasında yapılan anlaşmayla "Nahçıvan'ın tarım, sanayi, gıda ve tüketim mallarl, ulaşım, telekomünikasyon, inşaat ve turizm gibi alanlardaki acil ihtiyaçlarının karşılanması için toplam 100 milyon dolarlı bir kredinin Türkiye tarafindan tahsis edilmesine" karar verilmiştir. Bkz. TBMM Tutanak Dergisi, Dönem: 19, C: 9, Birleşim: 63, 14 Nisan 1992, s. 114-115.

${ }^{20}$ Gecikmeye dair RP Sakarya Milletvekili Cevat Ayhan'ın eleştiride bulunmuştur: “...Anlaşmanın Meclise sevkinin çok geç olduğunu ifade etmek istiyorum. Hatırlarsanız, Azerbaycan'da, 1990 yllının Ocak ayında Ruslarla birtakım çatışmalar olmuş, Bakü'de vahim birtakım olaylar meydana gelmiş, Rus tankları Azerileri ezmiş, katletmiş ve ardından da hemen, Azerbaycan Meclisi bağımsızlık ilan etmişti. Yani, olayları daha önceden tahmin edip gelişmesini değerlendirip tedbir almak da hükümetlerin görevidir; ancak, olayların ayan beyan olduğu 1990 Ocak ayından bu yana, hatırlarsanız, üç seneden fazla zaman geçmiştir. Üç yıllık bir dönemde bu tip anlaşmalar yapmayan, bu tedbirleri getirmeyen bir hükümetin veya hükümetlerin, bu meselede ne kadar lakayt, ilgisiz, gaflet içinde olduğunu burada üzülerek ifa ediyorum. Bakınız, bugünkü gazetelerde, 'Azerilere roket gönderdik' denmektedir. Yine bugünkü gazetelerde, 'Türkiye, resmen açılklanmamasına rağmen, Azerbaycan'a yardım taahhüdü altına girdi. Söz konusu yardımın, subay eğitimi, silah ve mühimmat olacağ bildirildi' denmekte ve buna dair birtakım zevatın beyanlarl... Türkçemizde bir söz var: 'Ba'de harâb-ül-Basra' Yani, Basra harap olduktan sonra siz bunlarl yaplyorsunuz; bunların bir klymeti yoktur...” Bkz.TBMM Tutanak Dergisi, Dönem: 19, C: 34, Birleşim: 92, 15 Nisan 1993, s. 203-204.
} 


\section{Selma GÖKTÜRK ÇETINKAYA}

Benzer şekilde CHP İçel Milletvekili İstemihan Talay da bu anlaşmanın gecikmiş olduğunu ve içeriğinin de yetersiz kaldığını belirtmiştir. Talay’a göre karşılıklı güvenlik savunma ve askeri yardımlaşma içerikli bir anlaşma yapılması gereklidir. Çünkü Azerbaycan, “Türkiye'nin uzun dönemli Kafkasya ve Orta Asya politikası açısından da bir eşiktir, vazgeçilmez bir ülke konumundadır" (TBMM, 15 Nisan 1993: 192, 209). Gecikmeler noktasında eleştirileri yanıtlayan Başbakan yardımcısı Erdal İnönü, anlaşmanın yeni onaylanacak olmasının işleyişi geciktirdiği algısına neden olduğunu, oysaki Azerbaycan'dan Türkiye'ye askeri öğrencilerin zaten gelmiş olduğunu ve eğitimlerinin de başladığını, bundan ayrı 2 bin öğrencinin de eğitimini Türkiye'de sürdürdüğünü, Azerbaycan'a sadece uçakla gönderilen insani yardımın tutarının 290 milyar lira olduğunu, Azerbaycan ve Nahcivan'a sürekli yardım yapıldığını söylemiştir (TBMM, 15 Nisan 1993: 219-220). Yapılan yardım ve verilen desteklerin hükümet tarafından sonradan açıklanmış olmasının nedenleri üzerinde durulması gerekmektedir. Türkiye'nin kendine yönelik tehditleri, iç ve dış tehlikeleri önlemek adına yardımları vaktinde söylememiş olması olasılığı fazladır. Eleştirilerin yoğun olduğu bu süreçte Türkiye'nin savunma işbirliğinden ziyade ülkesini savunacak Azerbaycan askerinin eğitimini amaçladığını da görmek gerekir. Buradan hareketle bahsi geçen anlaşma dokuz alanı kapsar mahiyette hazırlanmıştır. Buna göre eğitimler "Birlik, karargâh ve kurumlara askeri ziyaretler; Tatbikatlara gözlemci gönderme; Askeri lise eğitimi; Harp Okulu eğitimi; Sinıf Okulu eğitimi; Harp Akademileri eğitimi; Askeri Tip Akademisi ve Askeri Sağllk Okulları eğitimi; çeşitli kısa süreli kurslar; Birlik, Karargâh ve Kurumlarda Görevbaşı eğitimi" konularını içermektedir (TBMM Tutanak Dergisi, Türkiye Cumhuriyeti Hükümeti ile Azerbaycan Cumhuriyeti Hükümeti Arasında Askeri Eğitim İşbirliği Anlaşması, C. 34, 15 Nisan 1993: 12).

Sonrasındaki süreçte bu anlaşma, hava harp eğitimi hususunda da Azerbaycan'a eğitim desteği verilmesi kapsamında örnek teşkil etmiş ve 2008'de “Türkiye Cumhuriyeti Genelkurmay Başkanlığı ile Azerbaycan Cumhuriyeti Savunma Bakanlı̆̆g Arasında Azerbaycan Ali Harbi Tayyarecilik Mektebi’ne ĔgitimÖğretim Desteğine İlişkin Protokol” imzalanmıştır (Resmi Gazete, “Türkiye Cumhuriyeti Genelkurmay Başkanlığı ile Azerbaycan Cumhuriyeti Savunma Bakanlığı Arasında Azerbaycan Ali Harbi Tayyarecilik Mektebi'ne Eğitim-Öğretim Desteğine İlişkin Protokol”, 6 Şubat 2009: 1). 1992 tarihli anlaşma çerçevesinde 1994 senesinden itibaren Jandarma Genel Komutanlığına bağlı eğitim kurumlarında Azerbaycan'daki askeri personele eğitimler verilmeye başlanmıştır (Jandarma Genel Komutanlığ 1 Tarihi, C. 1, 2002: 488). 2009 tarihli protokole göre Azerbaycan Ali Harbi Tayyarecilik Mektebi'ne TSK tarafindan atama/görevlendirme yapılması; görevlendirilecek personelin kadro ve teşkilat yapısıyla görev süresinin de okulun eğitim ve öğretime yönelik ihtiyaçları veya Azerbaycan Savunma Bakanlığının bildireceği teklifler üzerine, TSK tarafından belirlenmesi uygun görülmüştür. Ayrıca Azerbaycan Ali Harbi Tayyarecilik Mektebi’nde görev yapacak Azerbaycan Cumhuriyeti Silahlı Kuvvetlerine mensup personelin görevlendirilmesinde, TSK'ya mensup subaylarla birlikte görev yapmış, TSK Eğitim Kurumları'nda eğitim görmüş, eğitim ve öğretim sistemine vakıf olmuş personele öncelik verilmiştir. Bundan ayrı Azerbaycan Ali Harbi Tayyarecilik Mektebi'nde görev yapacak TSK'ya mensup personelin seçiminde de buna benzer görevleri TSK'da yapmış olanlara 
öncelik verilmesi uygun görülmüştür. (Resmi Gazete, “Türkiye Cumhuriyeti Genelkurmay Başkanlığ1 ile Azerbaycan Cumhuriyeti Savunma Bakanlığı Arasında Azerbaycan Ali Harbi Tayyarecilik Mektebi’ne Eğitim-Öğretim Desteğine İlişkin Protokol”, 6 Şubat 2009: 1).

Bu bağlamda daha sonraki süreçte de iki ülke arasında pek çok anlaşma imzalanmıştır. Örneğin "Azerbaycan Cumhuriyeti İ̧̧işleri Bakanlığı Jandarma Komutanlı̆ğ Personeline Türkiye Jandarma Komutanlı̆ğ Tarafindan Verilecek Ĕgitim ve Araç Gereç Desteğine İliş̧kin Protokol" imzalanmıştır. Yine "Azerbaycan Cumhuriyeti Savunma Bakanlığı'na Türkiye Cumhuriyeti Silahlı Kuvvetleri Genelkurmay Başsanlı̆̆ Tarafindan Maliye Yardımı Yapılmasına Illişkin Protokol" vardır. "Azerbaycan Silahlı Kuvvetlerine Karşıllksız Askeri Yardım Yapılmasına IIlişkin Anlaşmalar”, "Kosova Türk Taburu Görev Kuvvetleri Bünyesinde Kosova'ya Gidecek Azerbaycan Birliğinin Çalışmalarına İlişkin Anlaşma”, "Azerbaycan Cumhuriyeti Savunma Bakanlığı Askeri Birimlerinin Eğitim Okullarının Oluşturulmasına İlişkin Protokol”, "Azerbaycan, Cumhuriyeti Savunma Bakanlı̆̆ı ile Türkiye Cumhuriyeti Silahlı Kuvvetleri Genelkurmay Başkanlı̆̆ Arasında Nahçıvan'daki 5 ci Ordunun Geliştirilmesine İlişkin Protokol" de bu kapsamda iki ülke arasında imzalanmıştır (Askerzade, 2009: 5; Darıc11, 2018: 52).

Bu işbirliği ve yardım içerikli anlaşmalar Azerbaycan'ın askeri statülü kolluk kuvveti olan Daxili Qoşunlar Komandanlıq1 (Azerbaycan Dahili Koşunlar Komutanlığı) ile yürütülmüş ve yürütülmeye devam etmektedir. Bu yapı, 1919'da “Azerbaycan Respublikası Daxili Qoşunları” (Azerbaycan Cumhuriyeti İç Birlikleri) adıyla Azerbaycan Demokratik Cumhuriyeti Parlamentosu tarafindan kurulmuştur. Azerbaycan'da Sovyet iktidarının kurulması sonrasında Dahili Koşunlar SSCB’ye devredilmiştir. Sovyet Rusya'nın çöküşünün ardından 1991 senesi Aralık ayında Bileceri kasabasında Azerbaycan'a bağl1 2500 asker ile Dahili Koşunlar kurulmaya başlanmıştır. Ancak 9 Mart 1995 tarihinde alınan karar doğrultusunda, Azerbaycan'ın toprak bütünlügü uğrunda Ermenistan'ın saldırılarına karşı mücadeleye başladığı gün olan 12 Mart tarihi, Dahili Koşunlar Günü olarak kabul edilmektedir (Azerbaycan Respublikası Daxili İşler Nazirliyinin Daxili Qoşunları. "Daxili Qoşunların Tarixi”, 2019). (Bkz. Ekler-Resim 1).Kısaca Karabağ Savaşı’na katılmış olduğu 12 Mart 1992, kuruluş tarihi olarak kabul edilmiş (Arıkan ve Hayal, 2015: 60) ve bu tarihten sonra Jandarma Genel Komutanlığı ile Azerbaycan Dahili Koşunlar Komutanlığı arasında çok yönlü temaslar başlamıştır. Bu temasların eğitim temelinde şekillenmiş olduğu muhakkaktır. Öyle ki Türkiye'nin gönderdiği askeri personeli vasıtasıyla Azerbaycan askeri okul ve birliklerinde verdiği eğitimler, genel olarak Azerbaycan Silahlı Kuvvetlerinin NATO ile işbirliğini artırması ve Azerbaycan askerlerinin Türkiye ve NATO eğitim merkezlerinde özel eğitimler alması amaçlıdır denilebilir (Askerzade, 2009: 7).

Kuruluşu itibariyle Azerbaycan'a desteğini sunan Türkiye, askeri yardımlarını da giderek artırmıştır. 4 Ekim 1994'te iki ülkenin İçişleri Bakanları tarafından imzalanan Güvenlik İşbirliği Anlaşması kapsamında 6 Eylül 1996'da Türkiye ve Azerbaycan İçişleri Bakanları görüşmelerde bulunmuşlardır ve Jandarma Genel Komutanlığının Azerbaycan Dahili Koşunlar Teşkilatına destek vermesi kararlaştırılmıştır. 10 Haziran 1996'da ise Genelkurmay Başkanlığı, Azerbaycan Hükümeti ile 


\title{
Selma GÖKTÜRK ÇETINKAYA
}

Askeri Alanda Eğitim, Teknik ve Bilimsel İşbirliği Anlaşması'nı imzalamıştır (Jandarma Genel Komutanlığı Tarihi, C. 1, 2002: 488). Askeri Alanda Eğitim, Teknik ve Bilimsel İşbirliği Anlaşması çerçevesinde 15 Kasım 1996 tarihinde Genelkurmay Başkanlığı şu direktifi vermiştir:

\begin{abstract}
“Öncelikle Azerbaycan'dan bir heyetin davet edilerek Jandarma Genel Komutanllğına ait birlik, kurum ve karargahları ziyaret etmelerinin sağlanması, müteakiben Jandarma Genel Komutanlı̆̆ından bir heyetin Azerbaycan'a gönderilerek birliklerin yerinde görülmesi; eğitim plan ve programlarının incelenip muhtemel eğitim vazife ve görevleri ile ihtiyaçlarının tespit edilmesi ve Azerbaycan'da görevlendirilecek bir Jandarma Ĕ̈itim Timi ile Dahili Koşunlar Teşkilatına gerekli desteğin sağlanması" (Jandarma Genel Komutanlığg Tarihi, C. 1, 2002: 489).
\end{abstract}

Verilen direktif doğrultusunda 7-12 Nisan 1997 tarihleri arasında Azerbaycan'dan gelen askeri heyet Jandarma Genel Komutanlığı karargahıyla bağlı birlikleri ziyaret etmiştir. Yine direktife uygun olarak 16-21 Haziran 1997'de Jandarma Genel Komutanlığından iade-i ziyaret yapılmış ve Azerbaycan Dahili Koşunlar Teşkilatına dair incelemelerde bulunulmuştur. Bu ziyaretlerin sonrasında Bakü'de 31 Ekim 1997'de Jandarma Genel Komutanlığı personeli tarafindan Azerbaycan Dahili Koşunlar Teşkilatı personeline eğitim-öğretim ve lojistik destek verilmesine dair protokol imzalanmıştır. Sonrasında bu eğitimleri verecek Türk Jandarma Eğitim Timi oluşturulmuş ve bu tim 28 Kasım 1997'de Bakü'ye gönderilmiştir. Aynı tarih itibariyle Bakü, Qala'da (Gala) Türkiye standartlarında modern bir okul yapılmaya başlanmış ve bu bina 29 Haziran 1998'de eğitim-öğretime açılmıştır (Jandarma Genel Komutanlığı Tarihi, C. 1, 2002: 489). 31 Ekim 1997 tarihli protokol kapsamında açılan Gala Eğitim Merkezi’ndeki personele Türk Jandarma Eğitim Timi tarafından eğitimler verilmeye başlanmıştır. Öncelikle iki sene süreli olarak zabit (subay) eğitimi gerçekleştirilmiştir. Ayrıca daha kısa süreli olmak üzere gizir (astsubay) ve mahe (uzman jandarma) eğitimleri de Gala bünyesinde Türkiye'den giden jandarma personeli tarafindan verilmiştir. Bu kapsamda 1559 Azerbaycan askeri personeli eğitime tabi tutulmuştur. Bundan ayrı Azerbaycan Dahili Koşunlar Komutanlığından 406 personel de Türkiye' de eğitim almıştır (Arıkan ve Hayal, 2015: 60).

Türkiye'den gönderilen ve Gala'da eğitim veren personelin başkanlığını albay rütbesinde olan ve "Dahili Koşunlar Komutanının Müşaviri" olarak görev yapan Jandarma Genel Komutanlığından bir subay üstlenmiştir. Verilen eğitimlerin bir kısmı da Türkiye'de gerçekleştirilmiştir. Bu kapsamda Azerbaycan'dan özellikle “Jandarma Subay Temel, Jandarma Komando, Keskin Nişancı Eğitimi, Muhabere Kursu, İngilizce Hazırlı, Askeri Köpek Timleri Eğitimcilerinin Hazırlı̆̆l, Liderlik ve İstihbarat Eğitimi”" kurslarına daha fazla askeri yetkili gönderilmiştir (Novruzov, 2019: 45-46). Ayrıca 1998'den 2001'e kadar Azerbaycan Dahili Koşunlar Komutanlığına 2.054.625 doları nakdi, 2.814.000 doları malzeme olmak üzere toplamda 4.868.625 dolar yardımda bulunulmuştur (Jandarma Genel Komutanlığı Tarihi, C. 1, 2002: 489). 2009 verilerine göre Türkiye'nin askeri reform için Azerbaycan'a 170 milyon ABD doları tutarında yardımı söz konusudur. Askeri teknik malzeme noktasında da Azerbaycan'dan desteğini esirgemeyen Türkiye'nin ürettiği ulaşım sistemlerini bugün Azerbaycan Silahlı Kuvvetlerinin Jandarma ve Milli Ordu'daki çoğu birlikleri, Nahçıvan'daki ordunun tümü kullanmaktadır. Ayrıca Azerbaycan asker ve gazileri Türkiye'deki askeri kurumlarda sağlık 
hizmetlerinden faydalanmaktadır. Türkiye'deki askeri düzene göre Azerbaycan'da oluşuma gidilmesi de önemli bir ayrıntıdır. Askeri yasama süreci, tüzükler, rütbeler Türkiye sistemine uygun şekilde geliştirilmektedir (Askerzade, 2009: 7, 10).

İlişkilerin geliştirilmesi noktasında askeri personelin karşıllklı ziyaretleri de oldukça mühimdir. Bu doğrultuda Jandarma Genel Komutanlığı ile Azerbaycan Dahili Koşunlar Komutanlığı arasında pek çok ziyaret gerçekleştirilmiştir. Buna göre 11-13 Mayıs 1998'de Jandarma Genel Komutanı Orgeneral Fikret Ö. Boztepe Azerbaycan'a gitmiş (BCA, Fon: 30.18.1.2. Kutu: 930. Gömlek: 145. Sıra: 5), 2025 Temmuz 1998 tarihleri arasında ise Azerbaycan Dahili Koşunlar Komutanı Elşan Kazımov iade-i ziyarette bulunmuştur. Bu süreçte eğitim konusunda da gelişmeler yaşanmıştır. Nitekim 7-14 Haziran 1998 ve 22 Ağustos-1 Eylül 1998 arasında Azerbaycan Karaheybet Eğitim Merkezinde lider eğitimine tabi tutulan kursiyerler, Türkiye'ye gelmişler ve bu heyetteki Dahili Koşunlar Teşkilatında görevli subaylar Jandarma Genel Komutanlığına ait okul, kıta ve karargahları da incelemişlerdir. Yaklaşık bir buçuk ay sonra ise, 24 Ekim'de Gala Dahili Koşunlar Eğitim Merkezinde eğitim gören altısı yönetim kadrosundan geri kalanı kursiyer olmak üzere 67 kişi Türkiye’ye gelmiştir. İzmir/Foça, Manisa, Afyon ve Ankara'daki jandarma birliklerini ziyaret eden heyet 31 Ekim 1998'de Türkiye'den ayrılmıştır. Aynı sene içinde, 30 Kasım-4 Aralık 1998 tarihlerinde Jandarma Genel Komutanlığı Harekat Başkanı Tümgeneral Mehmet Çavdaroğlu başkanlığındaki bir heyet, Gala Dahili Koşunlar Eğitim Merkezini ziyaret etmiştir (Novruzov, 2019: 46).

3-5 Mayıs 1999 tarihleri arasında Jandarma Genel Komutanı Orgeneral Rasim Betir Azerbaycan'a gitmiştir. Bu tarihten yaklaşık bir sene sonra da Azerbaycan Dahili Koşunlar Komutanı Elşan Kazımov'un 26 Haziran 2000'de Türkiye'ye geldiğini ve 1 Temmuza kadar ziyaretlerini devam ettirdiğini görmekteyiz. 16-20 Ekim 2000 tarihleri arasında ise Jandarma Genel Komutanlığ Harekat Başkanı Tümgeneral Osman Özbek Gala'da denetleme gerçekleştirmiştir. 30 Nisan 2001'de Azerbaycan'a giden Jandarma Genel Komutanı Orgeneral Aytaç Yalman'ın bu ziyareti 2 Mayıs'a kadar devam etmiştir. Dahili Koşunlar Komutanlığından da 2001 senesi içinde 16-23 Temmuz, 18-25 Haziran ve 3-10 Aralık tarihleri arasında Türkiye'ye ziyaretler gerçekleştirilmiştir. (Jandarma Genel Komutanlığ1 Tarihi I 2002: 490-491). 21 Ağustos 2001'de ise Genelkurmay Başkanı Orgeneral Hüseyin Kıvrıkoğlu Azerbaycan'ın ilk askeri öğrencilerinin mezuniyetine katılmak için on savaş uçağıyla Bakü’ye gitmiştir. 24 Ağustos'ta Türk Yıldızları Hazar'ın kıyısında gösteri uçuşu gerçekleştirmiştir (Babayeva, 2013: 79). Sonrasındaki yıllarda da gerek ziyaretler gerekse eğitimler iki ülke arasında devam etmiştir. Örneğin Dahili Koşunların Komando birliklerine 1-3 Haziran 2008 tarihleri arasında Jandarma Komando Özel Asayiş Komutanlığı Mobil Eğitim Birliği tarafından "Rehine Kurtarma ve Terörle Mücadele" eğitimi verilmiştir (Novruzov, 2019: 46). 


\section{Selma GÖKTÜRK ÇETINKAYA}

\section{Dahili Koşunların Âli Harbi Mektebi’nin Kurulması ve Türkiye-Azerbaycan İlişkileri}

Özellikle Gala Eğitim Merkezi kapsamında daha da güçlendiğini gördüğümüz iki ülke arasındaki askeri eğitime dair ilişkilerin 2011'e değin devam ettiğini söyleyelim. Bu tarihten sonra ise Gala'nın yapısında değişikliğe gidilmiştir. Nitekim 25 Şubat 2011'de Azerbaycan Cumhurbaşkanı İlham Aliyev'in imzaladığı 1358 sayılı fermanla Gala Eğitim Merkezi, Dahili Koşunlar Komutanlığı Âli Harbi Mektebi'ne dönüştürülmüştür. Bu değişikliğe bağlı olarak 15 Eylül 2014'te Âli Harbi Mektebi’nde eğitim öğretim süreci dört yıla çıkarılmış ve bu tarihte ilk öğrencilerini almıştır. Aynı gün İçişleri Bakan Yardımcısı ve Dahili Koşunlar Komutanı olan Tümgeneral Şahin Memmedov'un yaptığı konuşmasında Türkiye'nin verdiği destekten şu şekilde bahsettiğini görmekteyiz:

"Âli Harbi Mektebinde görev yapan Türkiye Cumhuriyeti Jandarma Genel Komutanlığl subaylarının faaliyetlerini özel olarak belirtmek istiyorum. Onlar, Azerbaycan Cumhuriyeti Dahili Koşunlar Komutanlı̆̆ subayları ile birlikte Azerbaycan'ın gelecekteki gelişimi için gerekli olan bir amaca hizmet ederek profesyonel subay kadrosu hazırlyyorlar. Türkiye Cumhuriyeti Jandarma Genel Komutanlığına ve Âli Harbi Mektebinde çalışan tüm jandarma subaylarına içten saygılarımı bildiriyorum..." (Arıkan ve Hayal, 2015: 61).

Dahili Koşunlar Komutanlığı Âli Harbi Mektebi Komutanı Tuğgeneral İlqar Memmedov ise Türkiye'nin desteğini aynı gün şu sözlerle anlatmıştır:

"1997 yllindan başlayarak Türkiye'den görevlendirilen jandarma personeli, tecrübelerini bizimle paylaşmakta, Âli Harbi Mektebi'nde eğitimin daha iyi yapılabilmesi için tüm gayretleri ile çalışmaktadırlar. Biz de öğretmenlerimizi değişik zamanlarda pedagoji tecrübesini arttırmak için Türkiye'ye kursa göndermekteyiz. Yeni kurulan Âli Harbi Mektebi'nde kısa zamanda gelişmiş eğitim sisteminin kurulmasında Türk Jandarma Subaylarının büyük rolü vardır. Bugüne kadar hizmeti geçen Türk subaylarına teşekkür ederim..." (Arıkan ve Hayal, 2015: 62).

Âli Harbi Mektebi'nin açılmasından sonra da Türkiye ile Azerbaycan arasında askeri eğitimler verilmeye devam edilmiştir. Ayrıca ikili ziyaretler de sıklıkla süregelmiştir. Örneğin 14-17 Mayıs 2012 tarihlerinde Azerbaycan Devlet Serhat Hizmeti ve Azerbaycan Hususi Devlet Muhafaza Hizmeti Komutanlıklarından gelen dört kişilik askeri heyet, Jandarma Genel Komutanlığı Genel Plan Prensipler Başkanlığını, Jandarma Lojistik Komutanlığını ve Jandarma Özel Asayiş Komutanlığı'nı ziyaret etmiştir (Azerbaycan Heyeti J. Gn. K.lı̆̆ını Ziyaret Etti, Jandarma Dergisi, Eylül 2012: 71).Yaklaşık bir ay sonra da Azerbaycan İçişleri Bakanlığı'nın resmi davetlisi olarak 10-13 Haziran 2012 tarihlerinde Jandarma Genel Komutanı Orgeneral Bekir Kalyoncu başkanlığındaki heyet Azerbaycan'a gitmiştir. Orgeneral Kalyoncu; Azerbaycan İçişleri Bakanı Korgeneral Rami Usubov, Savunma Bakanı Korgeneral Sefer Abiyev ve Dahili Koşunlar Komutanı Tümgeneral Zakir Hasanov'u ziyaret etmiştir. Kalyoncu ayrıca Kuba şehrindeki Operasyon Alayı'na ve Bakü'deki Gala Eğitim Merkezi'ne de gitmiştir (Jandarma Genel Komutanı Orgeneral Bekir Kalyoncu Azerbaycan'1 Ziyaret Etti, Jandarma Dergisi, Eylül 2012: 67).

Bu dönemde de jandarma personeli tarafından gerçekleştirilen ziyaretlerin sadece inceleme temelli olmadığını, eğitsel manada da faaliyetlerin gerçekleştiğini yine belirtelim. Nitekim 24-27 Eylül 2012 tarihleri arasında Azerbaycan Dahili Koşunlar Komutanlığından dört kişilik heyet "Terörle Mücadele 
Alanında Tecrübe Aarktımı" amacıyla Foça Jandarma Okul Komutanlığında incelemeler yapmıştır. Ayrıca aynı tarihlerde Jandarma Komando Özel Asayiş Komutanlığı tarafından 11 subay, 19 astsubay ve 17 erbaş ve er olmak üzere Azerbaycan Dahili Koşunlar Komutanlığından 47 personele Ahmetli Motorlu Tugay Komutanlığında "Toplumsal Olaylara Müdahale Aracı (TOMA) Taktik Kullanımı Eğitimi”" verilmiştir (Azerbaycan Dahili Koşunlar Komutanlığı Personeline Yerinde Eğitim Verildi”, Jandarma Dergisi, Ocak 2013: 70; Azerbaycan Heyeti Jandarma Komando Okulunda İncelemelerde Bulundu, Jandarma Dergisi, Ocak 2013: 73). 4-8 Kasım 2013 tarihlerindeyse Jandarma Havacılık Komutanlığında Azerbaycan Dahili Koşunlar ve Hususi Devlet Muhafaza Hizmeti Komutanlıkları personelinden oluşan heyet, helikopter uçuş eğitimi ve bakım çalışmalarıyla ilgili incelemelerde bulunmuştur (Azerbaycan Heyeti Jandarma Havacılık Komutanlığında İncelemede Bulundu, Jandarma Dergisi, Ocak 2014: 71).

\section{Avrasya Askeri Statülü Kolluk Kuvvetleri Teşkilatı-TAKM Kapsamında Türkiye- Azerbaycan İliş̧kileri}

Küreselleşmenin beraberinde getirdiği ülkeler arasındaki işbirliğine dayalı yapılanmalar arasında jandarma ile ilgili teşkilatları da görmek mümkündür. Bu bağlamda 2013 yılında Türkiye ve Azerbaycan arasındaki jandarma teşkilatlarıyla ilgili ilişkilerinde önemli bir gelişme yaşanmıştır. Avrupa ve Akdeniz Jandarmalar ve Askeri Statülü Kolluk Kuvvetleri Birliği (FIEP) ve Avrupa Jandarma Kuvveti (AJK) üyeliklerinde edindiği deneyimle hareket eden Jandarma Genel Komutanlığı, Kasım 2009'da Orta Asya'daki askeri statülü kolluk kuvvetleri arasındaki ilişkileri güçlendirmek, karşılıklı dayanışma ve işbirliğini artırmak için çalışmalara başlamıştır (Mavuş, 2013: 19). Öncelikle Jandarma Genel Komutanlığ 1 tarafindan 2010'da Azerbaycan, Kırgızistan, Moğolistan, Kazakistan, Türkmenistan, Özbekistan ve Tacikistan'a gönderilen mektupla Türk dünyasının askeri bir teşkilat kurmasına dair davette bulunulmuştur. Davete Azerbaycan, Kırgızistan, Moğolistan ve Kazakistan'dan olumlu dönüş yapılmış, akabinde bu dört devletle 2 Mart 2011'de Türkiye'de ilk toplantı gerçekleştirilmiştir (Özalp, 2015: 129-130). Bu süreçte, 10 Mart 2011'de Türkiye ile Azerbaycan'ın 16 Ağustos 2010 Bakü’de imzaladığı Türkiye Cumhuriyeti ile Azerbaycan Cumhuriyeti Arasında Stratejik Ortaklık ve Karşılıklı Yardım Anlaşması da kabul edilmiştir (TBMM, 10 Mart 2011: 80-81). 23 maddelik bu anlaşmanın ilk altı maddesi askeri, siyasi ve güvenlik konularına dahilken 7, 8 ve 9 . Maddeleri ise askeri ve askeri teknik işbirliği konuları kapsamındadır. Buna göre ilk altı maddede karş11ıklı toprak bütünlüğünün ve devlet sınırlarının dokunulmazlığının teyidi üzerinde durulmuş, silahlı kuvvetlerin karşılıklı olarak ilişkilerinin geliştirilmesine odaklanılmıştır. Silahlı saldırı, askeri tecavüz, her çeşit terör, kitle imha silahlarının yayılması, örgütlü suçlar, kara paranın aklanması, yasadışı uyuşturucu ve insan ticareti, yasadışı göçle mücadelede ortak çaba ve işbirliği içinde olması amaçlanmıştır. Sonraki üç maddede ise savunma ve karşılıklı yardım kapsamında ortak askeri harekatların icra edilmesi amacıyla askeri altyapılarının geliştirilmesi, silahlı kuvvetlerin her yönden hazırlığı ve zaruri silah ve askeri araçlarla donatılması için gerekli tüm ulusal önemlerin alınması söz 


\section{Selma GÖKTÜRK ÇETINKAYA}

konusudur. Ayrıca savunma işbirliği çerçevesinde iki tarafın savunma ihtiyaçları ve güvenliği için savunma amaçlı ürünler ve maddi-teknik araçlar sağlanacak, savunma amaçlı ürünlerin tasarlanıp üretilecek, savunma hedefli hizmetler sağlanacak, ortak askeri tatbikatlar ve savunma hazırlığı ile ilgili faaliyetler gerçekleştirilecek, silahlı kuvvetler için uzmanlar yetiştirilecek, silahlı kuvvetlerin lojistik desteği sağlanacak, askeri tıp ve sıhhiye konusunda önlemler alınacaktır. (TBMM, 2011: 4-8).

2 Mart tarihli toplantıdan yaklaşık üç ay sonra ise, 7-10 Haziran 2011 tarihleri arasında Komutanlar Toplantısı düzenlenerek Avrasya Askeri Statülü Kolluk Kuvvetleri Teşkilatı kurulmasına dair "Niyet Beyanı” imzalanmıştır (“Avrasya Askeri Statülü Kolluk Kuvvetleri Teşkilatı (TAKM)”, 28 Aralık 2015). 25 Ekim 2011'de ise Türkiye Cumhuriyeti Cumhurbaşkanı Recep Tayyip Erdoğan ve Azerbaycan Cumhurbaşkanı İlham Aliyev arasında İzmir'de Yüksek Düzeyli Stratejik işbirliği Konseyi'nin ilk toplantısı yapılmış ve bölgesel istikrarın öne çıkarıldığı yaklaşık yirmi belge imza edilmiştir (Sarıahmetoğlu, Yeşilot, 2017: 30; http://www.mfa.gov.tr/turkiye-azerbaycan-siyasiiliskileri.tr.mfa).

Bölgesel düzenin sürekliliğini arzu eden Türkiye, Azerbaycan ve Kırgızistan arasında 25 Ocak 2013’te Avrasya Askeri Statülü Kolluk Kuvvetleri Teşkilatı kurulmuştur (Alpar, 2013: 97). 25 Ocak 2013 tarihli toplantıya katılamamakla beraber nota teatisi ile Moğolistan da bu yapıya katıldığını ifade etmiş, ancak sonrasında da Mutabakat Muhtırasını imzalayamamıştır. Avrasya Askeri Statülü Kolluk Kuvvetleri Teşkilatı (TAKM) ile ilk olarak Orta Asya'daki jandarmaların işbirliği amaçlanmış olsa da ilerleyen süreçte Akdeniz ve Avrupa Jandarmalarıyla da birlikte hareket edilmesi; bir nevi Türkiye'nin Asya ile Avrupa arasında köprü görevi görmesi planlanmıştır. Bu noktada suçla mücadele, harekât, personel, teşkilatlanma ve eğitim işbirliği; teknoloji, lojistik, araştırma ve geliştirme alanlarında deneyimlerin ve bilgilerin paylaşımı ve değişimi de hedeflenmiştir (Mavuş, 2013: 19-20). Yirmi maddelik mutabakat metni ile kurulan TAKM'ın dört komisyon ile faaliyet göstermesi hedeflenmiştir. Buna göre Harekat ve Teşkilatlanma Konuları Komisyonu, Suçla Mücadele Komisyonu, Personel ve Eğitim İşbirliği Komisyonu ile Lojistik, Teknoloji ve Araştırma-Geliştirme Konuları Komisyonu oluşturulmuştur (Özalp, 2015: 155-156).

Adı, kurucusu olan ülkelerin baş harfinden oluşan TAKM, üyeler arasında karşılıklı olarak bilgi ve deneyim değişimini hedeflerken bölgedeki tüm ülkelere de açık olduğunu kuruluşunda belirtmiştir. TAKM'ın sembolü olarak üye ülkelerin kültürlerinde önemli bir yeri olan at seçilmiştir. At resminin üzerindeki dört yıldız ise kurucu üyeler olan Türkiye, Azerbaycan, Kırgızistan ve Moğolistan'1 simgelemektedir (Bkz. Ekler-Resim 2). Sembolik at heykelinin dönem başkanlığına getirilen ülkede muhafaza edilmesi de uygun görülmüştür. Böylece bu heykel ilk olarak Azerbaycan Dahili Koşunlar Komutanı tarafindan Jandarma Genel Komutanlığına verilmiştir. Yani TAKM'ın ilk dönem başkanlığı için Türkiye uygun görülmüştür. (Türkiye TAKM'nin İlk Dönem Başkanı Oldu, Cumhuriyet, 30 Ocak 2013: 9). 
Türkiye, aynı zamanda Avrasya Askeri Statülü Kolluk Kuvvetleri Teşkilatı'nın daimi sekreteryalığı görevine de, üyelerin oy birliği ile getirilmiştir. Mayıs 2014'e kadar dönem başkanı olacak olan Türkiye'nin bu tarihte görevini Kırgızistan'a bırakmasına da 2013'ün Mayıs ayında karar verilmiştir. TAKM, katılımcı olan ülkelerin askeri statülü kolluk kuvvetleri arasında işbirliğini geliştirmeyi amaçlamaktadır. Bu teşkilat hiçbir ülkeye ya da kuruluşa karşı oluşturulmamıştır ve hedeflenen sadece barışa hizmet etmek, vatandaşlarına çağdaş kolluk hizmeti vermek olarak belirtilmiştir. Karşılıklı olarak ilişkilerin güçlendirilmesine de hizmet eden TAKM kapsamında taraf ülkelerin katılımıyla gerçekleştirilen toplantılar olmuştur. (Avrasya Askeri Statülü Kolluk Kuvvetleri (TAKM) Kuruldu, Jandarma Dergisi, Mayıs 2013: 4).

Bunlardan biri 3-6 Temmuz 2013'te Kırgızistan'ın Bişkek kentinde yapılan TAKM Komisyon toplantısıdır. Bu toplantıda "Dünyadaki Jandarmalar ve Askeri Statülü Kolluk Kuvvetleri ile Barışı Koruma Harekâtında Kullanımı" konusu gündemi oluşturmuştur (Avrasya Askeri Statülü Kolluk Kuvvetleri Teşkilatı Komisyon Toplantısı Kırgızistan'da Yapıldı”, Jandarma Dergisi, Eylül 2013: 71). TAKM ile ilgili tüm bu gelişmelere rağmen yukarıda da belirtildiği üzere Moğolistan, Avrasya Askeri Statülü Kolluk Kuvvetleri Teşkilatı'na katılacak olan askeri yapısını lağvettiği için mutabakat muhtırasını imzalayamamıştır. Bundan ayrı hazırlıklarını tamamlayamadığı için muhtırayı imzalayamayan Kazakistan da teşkilata girebilmek için sonrasında müracaat etmiştir. Bu sebeple Avrasya Askeri Statülü Kolluk Kuvvetleri Teşkilatının gözden geçilerek yenilenmesine dair karar alınmıştır. Ancak halen bu teşkilatın faal hale gelmesi durumu söz konusu olmamıştır (Özalp, 2015: 151-153). Bu durumun küresel ve bölgesel tehditlerden kaynaklandığına dair bir yorum yapılabilir. Öte yandan yapılan araştırmalarda bununla ilgili herhangi bir bilgiye yahut bulguya ulaşılamadı̆g da belirtilmelidir.

TAKM merkezli görüşmelerden ayrı Türkiye ile Azerbaycan'ın ikili ilişkileri de bu süreçte devam edegelmiştir. Bu kapsamda 3-6 Şubat 2014 tarihleri arasında Jandarma Genel Komutanı Orgeneral Servet Yörük'ün resmi davetlisi olarak Türkiye'ye gelen Azerbaycan Dahili Koşunlar Komutanı Tuğgeneral Şahin Memmedov ve beraberindeki heyet; Jandarma Eğitim Komutanlığı, Jandarma Lojistik Komutanlığı, Ankara Jandarma Bölge Komutanlığı, Jandarma Kriminal Daire Başkanlığı, Jandarma ve beraberindeki heyet, Jandarma Eğitim Komutanlığı, Jandarma Lojistik Komutanlığı, Ankara Jandarma Bölge Komutanlığı, Jandarma Kriminal Daire Başkanlığı, Jandarma Komando Özel Asayiş Komutanlığı ve Ankara İl Jandarma Komutanlığı'nı ziyaret etmiştir (Dahili Koşunlar Komutanı Ülkemizde İncelemelerde Bulundu, Jandarma Dergisi, Haziran 2014: 11). Azerbaycan İçişleri Bakanı Korgeneral Ramil Usubov'un resmi davetlisi olan Jandarma Genel Komutanı Orgeneral Abdullah Atay ve beraberindeki heyet ise, 11-14 Kasım 2014 tarihleri arasinda Azerbaycan'a gitmiştir. Usubov'dan ayrı Savunma Bakanı Korgeneral Zakir Hasanov, Devlet Serhat Hizmetleri Komutanı Korgeneral Elçin Guliyev ve Dahili Koşunlar Baş İdaresi Komutanı Tuğgeneral Şahin Memmedov ile görüşülmüş ve Dahili Koşunlar Baş İdaresi birliklerinde incelemelerde 


\section{Selma GÖKTÜRK ÇETINKAYA}

bulunulmuştur (Jandarma Genel Komutanı Orgeneral Abdullah Atay, Katar ve Azerbaycan'da İncelemelerde Bulundu, Jandarma Dergisi, Ocak 2015: 73).

\section{Sonuç}

Türkiye Cumhuriyeti, kardeş ülke Azerbaycan Cumhuriyeti'ni kurulduğu andan itibaren her konuda desteklemeye gayret göstermiştir. Tarımdan ekonomiye, ulaşımdan sağlığa çok yönlü olarak resmi temaslarda bulunan iki ülke, Karabağ Meselesi nedeniyle askeri sahada birlikte hareket etmeyi oldukça yavaş ele almışlar, hatta sonraya bırakmışlardır. Coğrafi konumlarının verdiği gereklilikle Türkiye'nin ihtiyatlı duruşu ve fakat milli hissiyattan doğan birlikte hareket etme duygusu, ilk günden beri birbiriyle çarpışma yaşayarak gelişme göstermiştir. Doksanlı yıllarda Türkiye'de iç politikada en çok konuşulan meselelerin başında gelen Azerbaycan'a askeri yardım yapılması, zaman içerisinde gerçeğe dönüşmüştür. Bu bilgiden hareketle Azerbaycan'ın askeri yapılanmasında Türkiye'nin teorik ve pratik bilgilerle sağladığı desteği görmek gerekmektedir. Türkiye'den görevlendirilen askeri uzmanlar ve ağırlıklı olarak Jandarma Genel Komutanlığı personelleri; gerek Azerbaycan'a giderek verdikleri eğitimler, gerekse Türkiye'ye gelen ekiplere yönelik uyguladıkları kurslar ile Azerbaycan'ın kolluk kuvvetlerinin gelişiminde büyük rol oynamışlardır.

Askeri eğitime ilaveten Türkiye sağladığı askeri kapsamdaki teçhizat, sistem ürünleri ve maddi yardımlarla da Azerbaycan'a destek vermiştir. Bu eğitim ve yardımlar iç güvenliği de sağlayabilmek gayesiyle askeri kolluk kuvvetlerinin gelişimini de kapsar mahiyettedir. İki kardeş ülkenin bulundukları coğrafyanın tehditlerine ve tehlikelerine karşı birlikte hareket ederek güçlü durabileceklerinin bilincinde bulunmaları, işbirliği konusunda daha da istekli olmalarını beraberinde getirmiştir. Türkiye'nin desteğiyle Azerbaycan'ın uluslararası teşkilatlar içerisindeki yeri sağlam temeller üzerinde şekillenmiştir. Büyük boyutlu yapılanmaların haricinde Türkiye ve Azerbaycan tarafından bölgesel oluşumlara da gereksinim duyulmuştur. Öyle ki iki ülke Avrasya merkezli bir teşkilatla yardımlaşmaya dayalı bir teşkilata gitmeyi de düşünmüşlerdir. Bu düşünce doğrultusunda oluşumu sağlanan TAKM, Moğolistan ve Kazakistan'ın gerekçeleri nedeniyle aktif hale getirilememekle beraber plan doğrultusunda karşılıklı faaliyetler günümüzde de devam edegelmektedir. Örneğin 2017'de ilk kez Azerbaycan'dan Jandarma ve Sahil Güvenlik Akademisi'ne öğrenci gelmiştir ve bu öğrenciler mezuniyetleri sonrası Azerbaycan Cumhuriyeti İçişleri Bakanlığı Dahili Koşunlarında görevlerine teğmen rütbesiyle başlayacaklardır. Benzer şekilde Foça Jandarma Komando Okulu ve Eğitim Merkezi Komutanlı̆̆ı'nda da misafir askeri personel olarak Azerbaycan'dan gelen subay adayları 43 haftalık komando temel kursunda eğitim faaliyetlerini devam ettire gelmektedirler. Ayrıca yerinde eğitim desteğini devam ettiren Türk Jandarma Eğitim Timi, Azerbaycan Dahili Koşunlar Komutanlığında 25 jandarma personeli ile görevini sürdürmektedir. Bundan ayrı Azerbaycan-Türkiye (Şahdeniz) Doğal Gaz Boru Hattı da genel emniyet ve asayiş hizmetleri kapsamında korunmaktadır. 
Özetle Türkiye'nin Azerbaycan'a destek ve yardımları, karşılıklı güvenliğe dayalı işbirliği çalışmaları günümüzde de devam etmektedir. İki tarafın askeri statülü kolluk kuvvetlerinin karşılıklı olarak üst düzeyde ziyaretleriyle bu ilişkiler daha da güçlenmektedir. En yaygın harp türü olarak değerlendirebileceğimiz Vekalet Savaşları kapsamında büyük güçlerin bölgesel çatışmalarına karşı kendinin ve dost ülkelerin güvenliğini sağlamak gerekliliğinin bilinciyle hareket eden Türkiye Cumhuriyeti'nin Azerbaycan Cumhuriyeti ile diğer sahalarda olduğu üzere askeri alanda da yardım ve desteğe dayalı işbirliği, coğrafyanın barışını belirlemesi yönünden de dikkate değerdir. Dolayısıyla ilişkilerin devamlılığ konuyla ilgili pek çok akademik çalışma yapılmalıdır. Hazırlanan makale, yapılabilecek çalışmalar için örnek teşkil etme ve yol gösterici olma gayesi taşımaktadır.

\section{Kaynakça}

\section{Resmi Yayınlar}

BCA, Fon: 30.18.1.2. Kutu: 703. Gömlek: 268. Sira: 4. 14 Ocak 1992.

BCA, Fon: 30.18.1.2. Kutu: 714. Gömlek: 312. Sira: 10. 27 Nisan 1992.

BCA, Fon: 30.18.1.2. Kutu: 930. Gömlek: 145. Sira: 5. 3 Nisan 1998.

Resmi Gazete, "Türkiye Cumhuriyeti Hükümeti ile Azerbaycan Cumhuriyeti Hükümeti Arasında Askeri Eğitim İşbirliği Anlaşmasının Onaylanmasının Uygun Bulunduğuna Dair Kanun”, S. 21559, 21 Nisan 1993, s. 1.

Resmi Gazete, “Türkiye Cumhuriyeti Genelkurmay Başkanlığı ile Azerbaycan Cumhuriyeti Savunma Bakanlığı Arasında Azerbaycan Ali Harbi Tayyarecilik Mektebi'ne Eğitim-Öğretim Desteğine İlişkin Protokol", S. 27133, 6 Şubat 2009, s. 1.

TBMM Tutanak Dergisi, Dönem: 19, C. 1, Birleşim: 15, 12 Aralık 1991.

TBMM Tutanak Dergisi, Dönem: 19, C: 1, Birleşim: 16, 17 Aralık 1991.

TBMM Tutanak Dergisi, Dönem: 19, C: 2, Birleşim: 17, 18 Aralık 1991.

TBMM Tutanak Dergisi, Dönem: 19, C: 3, Birleşim: 29, 22 Ocak 1992.

TBMM Tutanak Dergisi, Dönem: 19, C: 4, Birleşim: 44, 4 Mart 1992.

TBMM Tutanak Dergisi, Dönem: 19, C: 5, Birleşim: 46, 10 Mart 1992.

TBMM Tutanak Dergisi, Dönem: 19, C: 7 , Birleşim: 54, 18 Mart 1992.

TBMM Tutanak Dergisi, Dönem: 19, C: 7 , Birleşim: 55, 19 Mart 1992.
TBMM Tutanak Dergisi, Dönem: 19, C: 8, Birleşim: 61, 25 Mart 1992.

TBMM Tutanak Dergisi, Dönem: 19, C: 9, Birleşim: 63, 14 Nisan 1992.

TBMM Tutanak Dergisi, Dönem: 19, C: 9, Birleşim: 66, 21 Nisan 1992.

TBMM Tutanak Dergisi, Dönem: 19, C: 9, Birleşim: 69, 28 Nisan 1992.

TBMM Tutanak Dergisi, Dönem: 1, C: 10, Birleşim: 74, 7 Mayıs 1992.

TBMM Tutanak Dergisi, Dönem: 19, C: 11, Birleşim: 78, 20 Mayıs 1992.

TBMM Tutanak Dergisi, Dönem: 19, C: 14, Birleşim: 89, 26 Haziran 1992.

TBMM Tutanak Dergisi, Dönem: 19, C:16, Birleşim: 94, 25 Ağustos 1992.

TBMM Tutanak Dergisi, Dönem: 19, C: 16, Birleşim: 97 (Olağanüstü), 28 Ağustos 1992.

TBMM Tutanak Dergisi, Dönem: 19, C: 17, Birleşim: 3, 16 Eylül 1992.

TBMM Tutanak Dergisi, Dönem: 19, C: 17, Birleşim: 5, 22 Eylül 1992.

TBMM Tutanak Dergisi, Dönem: 19, C: 19, Birleşim: 14, 13 Ekim 1992.

TBMM Tutanak Dergisi, Dönem: 19, C: 20, Birleşim: 21, 3 Kasım 1992.

TBMM Tutanak Dergisi, Dönem: 19, C: 20, Birleşim: 27, 17 Kasım 1992.

TBMM Tutanak Dergisi, Dönem: 19, C: 34, Birleşim: 92, 15 Nisan 1993.

TBMM Tutanak Dergisi, Dönem: 19, C: 37, Birleşim: 115, 22 Haziran 1993. 
TBMM Tutanak Dergisi, Dönem: 20, C: 26, Birleşim: 89, 6 Mayıs 1997.

TBMM Tutanak Dergisi, Dönem: 23, C: 96, Birleşim: 76, 10 Mart 2011.

TBMM Tutanak Dergisi, "Türkiye Cumhuriyeti Hükümeti ile Azerbaycan Cumhuriyeti Hükümeti Arasında Askeri Eğitim İşbirliği Anlaşması”, C. 34, 15 Nisan 1993, ss. 8-16.

TBMM Tutanak Dergisi, "Türkiye Cumhuriyeti ile Azerbaycan Cumhuriyeti Arasında Stratejik Ortaklık Ve Karşılıklı Yardım Anlaşması”, C. 96, 10 Mart 2011, ss. 4-8.

\section{Kurum Yayınları}

Harp Akademileri Komutanlığı (1993a), ABD Bakış Açısı ile Kafkaslar ve Orta Asya Devletleri, Harp Akademileri Basımevi, İstanbul.

Harp Akademileri Komutanlığı (1993b), Güney Kafkasya'nın Dünü-Bugünü-Yarını, Harp Akademileri Basımevi, İstanbul.

Jandarma Genel Komutanlığı (2002), Jandarma Genel Komutanlığı Tarihi, cilt: 1. (Asayiş ve Kolluk Tarihi İçerisinde Türk Jandarma Teşkilatı), Jandarma Genel Komutanlığı Yayınları, Ankara.

Ministry of Foreign Affairs of the Republic of Azerbaijan Department for Analysis and Strategic Studies (2017), Documents of International Organizations on the Armenia-Azerbaijan Conflict, Baku.

TBMM (1993), Yeni Bir Yüzyıla Doğru Türkiye ve Türk Cumhuriyetleri İlişkileri, Haz. Zakir Avşar, Ferruh Solak, Ayşe Yorulmaz, Ferhan Yorulmaz, TBMM Başkanlığı Yayınları, Ankara.

TBMM (2012), Tarihe Düşülen Notlar-2, Yabancı Devlet Adamlarının Genel Kurul Konuşmaları, Koordinatör: Rüçhan Akıncıoğlu, Editör: Hasan Yılmaz, TBMM Başkanlığı Yayınları, Ankara.

\section{Süreli Yayınlar}

Cumhuriyet (10 Kasım 1991). “Türkiye, Azerbaycan'ı Resmen Tanıdı”, s. 1-19.

Cumhuriyet (22 Aralık 1991). "SSCB Resmen Yok Oldu", s. 1-14.

Cumhuriyet (20 Mart 1992). “Erivan'dan Bakü'ye Savaş Sinyalleri”, s. 1-19.

Cumhuriyet (20 Mart 1992). “Azerbaycan'a Yardim Yok", s. 11.

Cumhuriyet (17 Haziran 1992). "Elçibey Yemin Etti”, s. 8.

Cumhuriyet (2 Kasım 1992). "Azerbaycan ile İlişkiler Geliştirildi”, s. 17.

Cumhuriyet (15 Nisan 1993). “Özal, Bakü’ye Askeri İttifak Önerdi”, s. 1-17
Cumhuriyet (30 Ocak 2013). “Türkiye TAKM'nin İlk Dönem Başkanı Oldu”, s. 9.

Hürriyet (5 Mayıs 1992). "Türkeş Azerbaycan Seçim Kampanyasında”, s. 1-30.

Hürriyet (19 Haziran 1993). “Azerbaycan'da Aliyev Darbesi”, s. 1.

Hürriyet (15 Ocak 1994). “Azeri Şahlanışı”, s. 119.

Hürriyet (19 Eylül 2002). "Rüya Gerçek Oldu”, s. 1-11.

Milliyet (23 Ocak 1992). "Bakü'de Coşku Var”, s. 17.

Milliyet (19 Haziran 1993). "Elçibey Krizi”, s. 1.

Jandarma Dergisi (Eylül 2012). "Jandarma Genel Komutanı Orgeneral Bekir Kalyoncu Azerbaycan'1 Ziyaret Etti” 134: 67.

Jandarma Dergisi (Eylül 2012). “Azerbaycan Heyeti J. Gn. K.lığını Ziyaret Etti” 134: 71.

Jandarma Dergisi (Ocak 2013). “Azerbaycan Dahili Koşunlar Komutanlığı Personeline Yerinde Eğitim Verildi" 135: 70.

Jandarma Dergisi (Ocak 2013). “Azerbaycan Heyeti Jandarma Komando Okulunda İncelemelerde Bulundu” 135: 73.

Jandarma Dergisi (Mayıs 2013). “Avrasya Askeri Statülü Kolluk Kuvvetleri (TAKM) Teşkilatı Kuruldu" 136: 4.

Jandarma Dergisi (Eylül 2013). “Avrasya Askeri Statülü Kolluk Kuvvetleri Teşkilatı Komisyon Toplantısı Kırgızistan'da Yapıldı" 137: 71.

Jandarma Dergisi (Ocak 2014). “Azerbaycan Heyeti Jandarma Havacılık Komutanlığında İncelemede Bulundu” 138: 71.

Jandarma Dergisi (Haziran 2014). "Dahili Koşunlar Komutanı Ülkemizde İncelemelerde Bulundu" 139: 11.

Jandarma Dergisi (Ocak 2015). "Jandarma Genel Komutanı Orgeneral Abdullah Atay, Katar ve Azerbaycan'da İncelemelerde Bulundu" 141: 73.

\section{Tetkik Eserler}

Alpar, Güray. (Mayıs 2013). “Güvenliğin Sağlanmasında Bir Kolluk Kuvveti Olan Jandarmanın Geçmişten Günümüze Rolü ve Dünyadaki Konumu", Güvenlik Bilimleri Dergisi, cilt: 1, s. 79-106.

Arıkan, Hidayet \& Hayal, Ünal. (2015). "Azerbaycan Dahili Koşunlar Komutanlığ Âli Harbi Mektebi (DQAHM)", Jandarma Dergisi, say1: 142 , s. 58-65. 
Armaoğlu, Fahir. 20. Yüzyıl Siyasi Tarihi, İstanbul, Alkım Yayınevi, 2005.

Arslan, Yasin. (Kış 1994). "Azerbaycan Bilmecesi, Petrol, Darbeler ve Gerçekler”, Avrasya Dosyası, cilt: 1, say1: 95, s. 211-218.

Askerzade, Aygün. (Kış 2009). "NATO Çerçevesinde Azerbaycan-Türkiye Askeri Siyasi İşbirliği ve Bölgesel Güvenlik Sorunları", Karadeniz Araştırmaları, sayı: 20, s. 1-17.

Aydın, Ulviyye. (2018). “Türkiye-Azerbaycan İlişkilerinin Son On Y1lı (2006-2016): Kardeşlikten Stratejik İşbirliğine Uzanan Yol”, Avrasya Uluslararası Araştırmalar Dergisi, cilt: 13, say1: 6, s. 38-62.

Babayeva, Vefa. (2013). Haydar Aliyev Dönemi Türkiye-Azerbaycan İlişkileri, Yüksek Lisans Tezi, İstanbul Ticaret Üniversitesi Sosyal Bilimler Enstitüsü Uluslararası İlişkiler Anabilim Dalı.

Bilgin, Taner. Bir Türk Beyi Ebulfez Elçibey, İstanbul, Babıali Kültür Yayıncılığı, 2016.

Darıcılı, Ali Burak. "Türkiye ve Azerbaycan Arasındaki Askeri İşbirliği Süreçlerinin Analizi”, Türkiye-Türk Dünyası İlişkileri 'Politik ve Ekonomik Boyut', Edt: İlyas Topsakal, Sema Ay, Bursa, Ekin Yayınevi, 2018, s. 49-61.

Haydaroğlu, Ceyhun. "Türkiye Avrasya İlişkileri Bağlamında Enerjinin Jeopolitiği”,, 21. Yüzyılda Küresel ve Bölgesel Aktörler Bağlamında Türk Dış Politikası, Edt: Murat Ercan, İstanbul, Efe Akademi Yayınlar1, 2018, s. 595-618.

Mardanov, Samir. “Azerbaycan Dış Politikalarının Temelleri (1991-2003)”, Kafkasya'nın Yükselen Yıldızı İlham Aliyev Döneminde Azerbaycan, Edt: Çağrı Erhan, Ankara, Atatürk Araştırma Merkezi Yayınlar1, 2013, s. 47-102.

Mavuş, Polat. (2013). "Dünya Jandarmaları ve Askeri Statülü Kolluk Kuvvetleri Arasında İşbirliği Faaliyetleri", Jandarma Dergisi, say1: 136, s. 16-23.

Novruzov, Tural. (2019). "Bir Azerbaycanlı Subayın Kaleminden: Azerbaycan-Türkiye Jandarma İlişsileri”, Jandarma Dergisi, sayı: 153, s. $42-47$.

Özalp, Görkem Ozan. (2015). Avrasya Askeri Statülü Kolluk Kuvvetleri Teşkilatı (TAKM), Yüksek Lisans Tezi, Necmettin Erbakan Üniversitesi Sosyal Bilimler Enstitüsü Tarih Anabilim Dalı.

Saray, Mehmet. Türk Dünyasında Dil ve Kültür İşbirliği, İstanbul, Çantay Kitabevi, 2003.

Saray, Mehmet. Türkiye ve Yakın Komşuları, Ankara, Atatürk Araştırma Merkezi Yayınları, 2010.
Sarıahmetoğlu, Nesrin. Karabağ, İstanbul, IQ Kültür Sanat Yayıncılık, 2011.

Sarıahmetoğlu, Nesrin \& Yeşilot, Okan, "Azerbaycan Cumhuriyeti”, Bağımsılıklarının 25. Yılında Türk Cumhuriyetleri, Edt. Abdulvahap Kara, Fahri Solak, İstanbul, Türk Dünyası Belediyeler Birliği Yayınları, 2017, s. 7-72.

Yalçınkaya, Alaeddin. "Türk Diş Politikasında Kafkasya”, 21. Yüzyılda Küresel ve Bölgesel Aktörler Bağlamında Türk Dış Politikası, Edt: Murat Ercan, İstanbul, Efe Akademi Yayınları, 2018, s. 565-594.

Yilmaz, Reha \& Sayın, Fatih Mehmet. (2013). “Azerbaycan Dış Politikasını Belirleyen Öğeler ve Denge Politikasına Yansımaları”, Çankırı Karatekin Üniversitesi Sosyal Bilimler Enstitüsü Dergisi, cilt: 4, sayı: 1, s. 23-42.

\section{Elektronik Kaynaklar}

Azerbaycan Respublikası Daxili İşler Nazirliyinin Daxili Qoşunları. "Daxili Qoşunların Tarixi" https://dq.mia.gov.az/?/az/menu/13/,2 [Erişim tarihi: 20.11.2019].

Milliyet. "Türk Dünyası Ortak Ordusunu Kuruyor" http://www.milliyet.com.tr/gundem/turk-dunyasiortak-ordusunu-kuruyor-2571475, [Erişim tarihi: 20.11.2019].

"Avrasya Askeri Statülü Kolluk Kuvvetleri Teşkilatı (TAKM)" http://web.archive.org/web/20151228225435/http:// www.jandarma.tsk.tr:80/dis/takm.htm, [Erişim tarihi: 20.11.2019].

"Ortak Türk Ordusu Kuruldu" https://www.stratejikortak.com/2017/12/ortak-turkordusu-kuruldu.html, [Erişim tarihi: 20.11.2019].

Azerinfo. "12 Mart - Daxili Qoşunlar Günüdür" http://azerinfo.az/gundem/10335-12-mart-daxiliqoshunlar-gunudur.html, [Erişim tarihi: 21.11.2019].

Türkiye Cumhuriyeti Bakü Büyükelçiliği. "Büyükelçilik Tarihi ve Önceki Büyükelçilerimiz" http://baku.emb.mfa.gov.tr/Mission/MissionChiefH istory, [Erişim tarihi: 24.02.2020].

Türkiye Cumhuriyeti Dışişleri Bakanlığı. "TürkiyeAzerbaycan Siyasi İlişkileri” http://www.mfa.gov.tr/turkiye-azerbaycan-siyasiiliskileri.tr.mfa, [Erişim tarihi: 25.02.2020].

Azərbaycan Respublikası Xarici İşlər Nazirliyi. "Türkiyə Respublikası" http://www.mfa.gov.az/az/content/151/turkiye, [Erişim tarihi: 25. 02. 2020].

32. Gün. "Ebülfez Elçibey: Türkiye'den dörd helikopter istedim vermediler" https://www.youtube.com/watch?v=5G7qRrekx-k,

[Erişim tarihi: 28.02 .2020 ]. 


\section{Ekler}

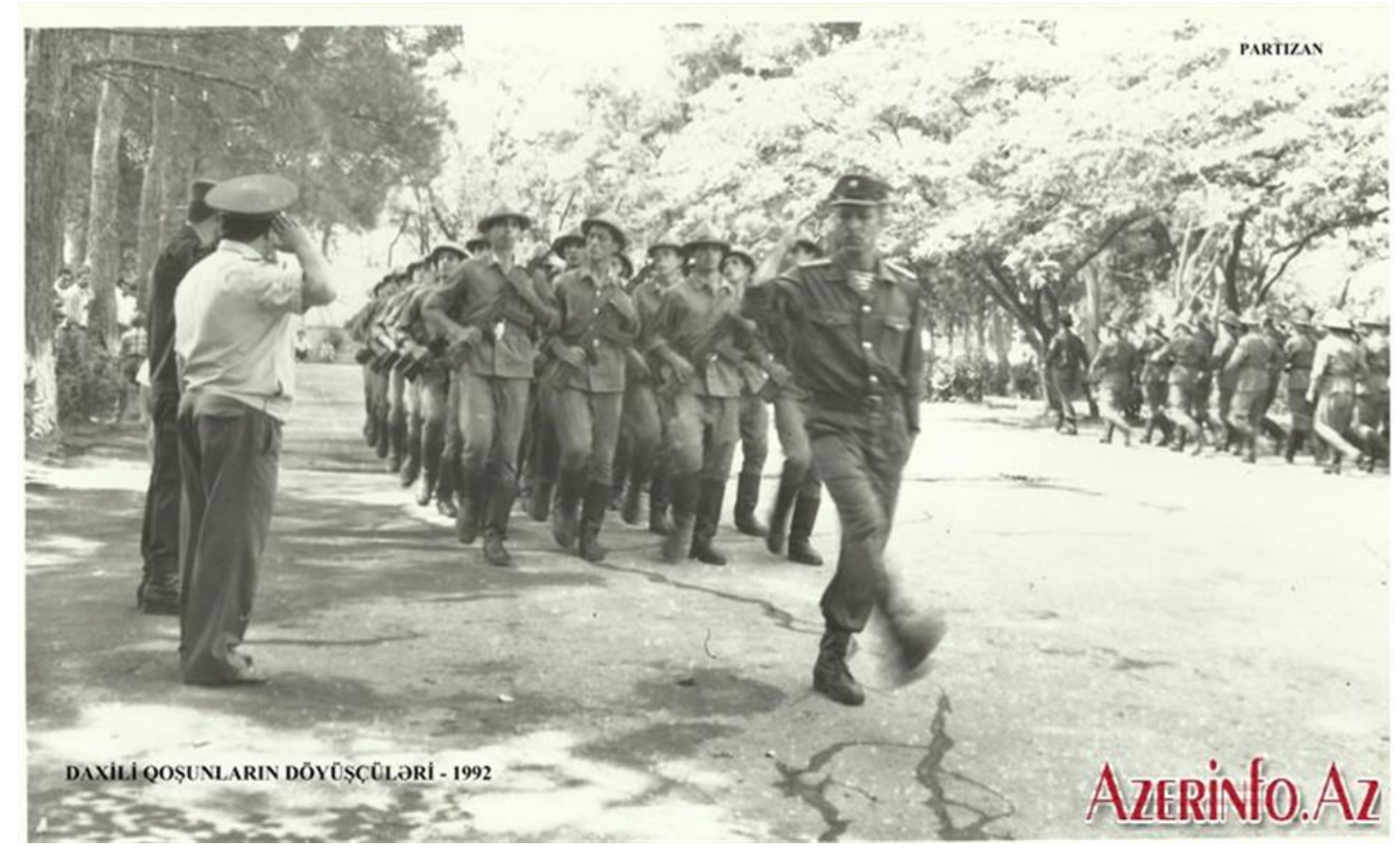

Resim 1: Azerinfo, “12 Mart - Daxili Qoşunlar Günüdür”, 12 Mart 2016.



Resim 2. Avrasya Askeri Statülü Kolluk Kuvvetleri Teşkilatı'nın Amblemi. Milliyet, “Türk Dünyası Ortak Ordusunu Kuruyor” 13 Aralık 2017. 